\title{
41- İstanbul yabancılar için Türkçe (C1) ders kitabı ile Almanca em neu (C1) Abschlusskurs ders kitabının kültürlerarası yaklaşım açısından karşılaştırılması
}

Faik ÖMÜR'1

APA: Ömür, F. (2021). İstanbul yabancılar için Türkçe (C1) ders kitabı ile Almanca em neu (C1) Abschlusskurs ders kitabının kültürlerarası yaklaşım açısından karşılaştırılması. RumeliDE Dil ve Edebiyat Araştırmaları Dergisi, (25), 696-725. DOI: 10.2900o/rumelide.1032519.

Öz

Bu çalışmanın amacı Türkçenin yabancı dil olarak öğretimi için hazırlanmış olan İstanbul Yabancılar İçin Türkçe (C1) Ders Kitabı ile Almancanın yabancı dil olarak öğretimi için hazırlanmış olan em neu Abschlusskurs Deutsch als Fremdsprache (C1) Ders Kitabının kültürlerarası yaklaşım açısından karşılaştırmak ve çalışmanın sonunda hangi ders kitabında kültürlerarası yaklaşıma göre daha fazla kültürel ögeye yer verildiğini sayısal verilerle tespit etmektir. İstanbul Yabancılar İçin Türkçe Ders Kitabı Türkiye'de öğrenim gören yabancı öğrencilere Türkçeyi öğretmek için TÖMER’lerde, em neu Ders Kitabı ise üniversitelerin Alman Dili Eğitimi bölümlerinde dil öğretiminde kullanılmaktadır. Bu nedenle bu iki kitap tercih edilmiştir. Bu çalışmada İstanbul Yabancılar İçin Türkçe Ders Kitabı (C1)'nda yer alan metinlerle, Almanca em neu Abschlusskurs Deutsch als Fremdsprache (C1) Ders Kitabında yer alan metinler (okuma-anlama, dinleme-anlama, yazma ve konuşma metinleri ile bunlara ek olarak verilmiş diğer bölümlerde geçen kültürden kültüre, ya siz? , medeniyetimize yön verenler, resimler, çizimler, sözcük dağarcı̆̆ı gibi kültürü yansitan diğer unsurlar) kültürlerarası yaklaşım açısından doküman incelemesi metoduyla karşılaştırılmıştır. Öncelikle her ünite tek tek ele alınmış ve metinler içinde geçen kültür(ler)e ait ögeler tablo içinde gösterilmiştir. Daha sonra tabloların sonunda ünitede geçen kültürel ögelerle ilgili kısa bir açıklama yapılmıştır. Sonuç ve öneriler bölümünde, kültürlerarası yaklaşıma göre daha çok IYİT Ders Kitabının önem verdiği sayısal verilerle teyit edilmiş ve dolayısıyla IYİT Ders Kitabında daha fazla kültürel ögenin yer aldığı belirlenmiştir. Ayrıca yabancı dil öğretiminde bu yaklaşıma göre yapılacak dil öğretimi için önerilerde bulunulmuştur. Son olarak bu yaklaşımın yabancı dil öğrenmeye olan katkısı da tartışılmıştır.

Anahtar kelimeler: Kültürlerarası yaklaşım, yabancı dil öğretimi, kültür, karşılaştırma, ders kitabı

\section{Comparison of Istanbul foreigners Turkish (C1) course book and German em neu (C1) Abschlusskurs course book in terms of intercultural approach}

\begin{abstract}
The aim of this study is to compare the Istanbul Turkish For Foreigners (C1) Course Book, which was prepared for teaching Turkish as a foreign language, and the em neu Abschlusskurs Deutsch als Fremdsprache ( $\mathrm{C} 1$ ) Course Book, which was prepared for teaching German as a foreign language, in terms of intercultural approach. The main concern of this study is to determine which course book contains more cultural elements compared to the intercultural approach with numerical data at the end of the study. Relatedly, the texts in the Istanbul Turkish for Foreigners Course Book (C1) and the texts in the German em neu Abschlusskurs Deutsch als Fremdsprache (C1) Course Book (reading-
\end{abstract}

Dr. Öğr. Üyesi, Nevşehir Hacı Bektaş Veli Üniversitesi, Eğitim Fakültesi, Yabancı Diller Bölümü, Alman Dili Eğitimi ABD (Nevşehir, Türkiye), faikomur@nevsehir.edu.tr, ORCID ID: 00oo-00o3-4839-3096 [Araştırma makalesi, Makale kayıt tarihi: 13.08.2021-kabul tarihi: 20.10.2021; DOI: 10.29000/rumelide.1032519] 
comprehension, listening-comprehension, writing and speaking texts, in addition to other elements reflecting the culture, such as from culture to culture, or you, those who shape our civilization, pictures, drawings, vocabulary mentioned in other chapters) were compared with the document analysis method in terms of intercultural approach. First of all, each unit was handled one by one and the cultural elements mentioned in the texts are shown in the table. Then, at the end of the tables, a short explanation was given about the cultural elements of the unit. In the conclusion and suggestions section, it has been confirmed with the numerical data that the İstanbul Turkish For Foreigners Course Book (C1) has more emphasize on intercultural approach and accordingly, it has been determined that it has more cultural elements. In addition, the contribution of this approach to foreign language learning has been also discussed.

Keywords: İntercultural approach, foreign language teaching, culture, comparison, course book

\section{Giriş}

Dil, insanlar arasında anlaşmayı sağlayan bir vasıtadır. Her insan bir dili öğrenme yetisiyle dünyaya gelir. Ancak insan kendi ana dilinden başka dilleri de öğrenmek ister. Yeni bir dili öğrenirken o dilin kültürünü de öğrenmek gerekir. Bu nedenle ders kitaplarında dilin ayrılmaz parçası olan kültürel ögelerle ilgili metinlere veya görsellere de yer verilmektedir. Bu yüzden çalışmaya önce kültür kelimesinin tanımı ile başlamak daha isabetli olacaktır. Türk Dil Kurumu’nun çıardığı Türkçe Sözlük kültür kelimesini şöyle tanımlamaktadır:

1. Tarihi, toplumsal gelişme süreci içinde yaratılan bütün maddi ve manevi değerler ile bunları yaratmada, sonraki nesillere iletmede kullanılan, insanın doğal ve toplumsal çerçevesine egemenliğinin ölçüsünü gösteren araçların bütünü, hars, ekin.

2. Bir topluma veya halk topluluğuna özgü düşünce ve sanat eserlerinin bütünü.

\section{Bireyin kazandığı bilgi. (Kültürlü kişi)}

4. Biyolojide uygun biyolojik bir mikrop türünü üretme.

\section{Tarım.}

6. Muhakeme, zevk ve eşleştirme yeteneklerinin öğrenim ve yaşantılar yoluyla geliştirilmiş olan biçimi (TDK Türkçe Sözlük, 2011: 1558).

Ziya Gökalp kültür kelimesine karşılık olarak hars kelimesini kullanmıştır. Ona göre kültür kelimesinin iki anlamı vardır: 1. Hars 2. Tehzib (terbiye etme, eğitim). Ziya Gökalp'e göre hars; halkın ananelerinden, eğilimlerinden, örflerinden, sözlü ve yazılı edebiyatından, estetik ve iktisadi ürünlerinden ibarettir (Ünalan, 2014: 147-148). Kısaca kültürü şöyle tarif edebiliriz: "Kültür, bir milletin geçmişe ait maddi ve manevi yaşantılarının toplamı; bugüne ait olarak da milleti oluşturan fertlerin duyuş, düşünüş ve davranış birliği içinde olmasıdır" (Ünalan, 2014: 153). Yukarıdaki tanımlardan da anlaşılacağı üzere kültür kavramı çok geniş anlamlar ifade etmektedir. Kısaca insanların ürettiği, yaptı̆̆ı, düşündüğü yaşamla ilgili her türlü maddi ve manevi eserlerin tümüdür. Bu çalışmada ele alınan kitaplarda kültürün parçalarından olan edebiyat, sanat, adet, gelenek, deyim, atasözleri vb. özellikleri karşılaştırılmıştır. Yousefi'nin tanımına göre, "Kültürlerarası (interkulturell) sıfatı, farklı kültürel geçmişlere sahip insanların birbirleriyle temasa geçtiği bir değişim sürecini tanımlar. Kültürel arka plan, öncelikle dini- 
kültürel bağlantıları, mistik-felsefi algıları, dili, sanatı ve hukuk sistemlerini, farklı düşünce ve yaşam biçimlerini içerir. Bilimsel bir disiplin olarak kültürlerarasılık, her tür fenomenoloji, antropoloji, sosyoloji ve kültürel felsefeyle ilgilidir. Kültürel formların bir kültürden başka bir kültüre aktarım sürecini ifade eder" (Yousefi, 2011: 29).

Yabancı dil öğretim metotları geleneksel ve alternatif diye iki gruba ayrılmaktadır. Geleneksel yabancı dil öğretim metotları arasında yer alan - aslında bu bir metottan ziyade yaklaşım olarak ele alınmaktadır- Kültürlerarası yaklaşım, Neuner ve Hunfeld'e göre: "Kültüre özgü, bireysel yaşantıları, öğrenme geçmişini, dünya bilgisini, öğrenme geleneklerini ve alışkanlıklarını, kaynak ve hedef kültürün ilişkisini, bireysel motivasyonu ve öğrenme başarısını ve kurumsal şartların yabancı dil öğrenmeye olan etkilerini araştırır" (Neuner ve Hunfeld, 1993: 124). Bu açıdan dil ile toplum arasında bir köprü gibidir. Dili, salt dilsel birimler olarak görmekten ziyade, o dilin ait olduğu toplumsal, sosyal ve kültürel ögelerle birlikte değerlendirilir.

Kültürlerarası yaklaşımı Rösler ise şöyle tarif etmektedir: "Benlik ve yabancı arasındaki etkileşimi ve dolayısıyla öğrencinin Alman dili ve kültürüne bakışını didaktik değerlendirmelerinin başlangıç noktası olarak alır” (Rösler, 2012: 82). Kısaca iki farklı dil ve kültür karşılaştırılır. Kültürlerarası yaklaşım adından da anlaşılacağı üzere en az iki kültürün etkileşimini ele alarak, yabancı dil öğrenen bireylerin; dil edinimini, öğrenenin hem kendi anadili hem de yabancı dil perspektifinden ele alır. Bu yöntemin amacı evrensel öğretim müfredatı hazırlayarak kültürlerarası anlaşmaya katkı sunmaktır. Bu yöntem, ön yargıları ve kalıplaşmış ifadeleri ortadan kaldırmak ister. Bunların yerine yabancı olana ilgi duyma ve toleransı teşvik eder. Öğrenenlerin hem yabancı hem de kendi kültürlerini var olan düşünce, konuşma ve uygulama biçimleri ile karşılaştırarak daha duyarlı olmaları hedeflenir. Öncelikli amaç yabancı kültürü bilmek değil, aksine yabancı kültüre karşı anlayışlı olmaktır.

Dili kültürlerarasılık açısından ele almak kültürlerarası öğrenme kavramını da beraberinde getirmektedir. Müller-Jacquier’e göre kültürlerarası öğrenme: "Farklı kültürlerden gelen insanlar arasında durumsal bir öğrenme sürecidir deneyimlerini paylaşmaktır. Kültürlerarası öğrenmenin ön koşulu, kültürlerarası iletişim sürecinde C1 / C2 seviyesindeki konuşmacı/dinleyicilerin ilişki içinde olmalarıdır. Kural olarak her türden bir dizi yabancı deneyimlerini paylaşmak" (Müller-Jacquier,1994). Kültürlerarası yaklaşıma göre hazırlanan kitaplarda ele alınan konular tamamen yaşam tecrübelerine dayanan konulardan seçilerek her yaşta öğrenenin ve farklı kültürlerden gelenlerin kendinden de bir şeyler bulabileceği veya karşılaştırma yapabileceği konulardan oluşmaktadır. (Neuner ve Hunfeld, 1993: 121). Öğrenme somuttan soyuta doğru ilerlemeli ki, öğrenenler zorluk çekmesin. Neuner ve Hunfeld'e göre bu yaklaşımda anlama becerilerine dönük okuma-anlama ve dinleme-anlama becerileri dersin/ kursun en başından itibaren verilir. Bunlarla ilgili konular hedef kültürün güncel yaşamını yansıtır. Seçilen metinler kullanımlık metinler değildir, aynı zamanda gerçekçi metinler, bilgilendirici metinler ve kurmaca metinlerden oluşur. Yani derslerde edebi metinler de yer alır. Bunların nihai amacı, hedef dilde konuşmayı sağlamaktır. Yöntemin başarısı; metin seçimine, öğrenenlerin amacına ve kabiliyetine bağlıdır. Ayrıca bu yöntem yazma becerisine ve bilinçli öğrenmeye de oldukça fazla yer verir (Neuner ve Hunfeld, 1993: 122).

Günümüzde küreselleşen dünyada insanların hareketliliği çok arttığından ister istemez seyahat edilen ülkenin dili ve kültürü de merak edilmektedir. Seyahatler değişik amaçlarla yapılmaktadır. Bazı insanlar turistik amaçlı, bazıları iş için, bazıları sağlık, bazıları da eğitim amaçlı bir ülkeye seyahat etmektedir. Hangi amaçla olursa olsun, insanların mutlaka bir yabancı dile ihtiyaç duymaktadır. Bu dil, gidilen ülkenin dili olmazsa da artık hemen hemen herkesin İngilizce bildiği kabul edilmektedir. Tüm ülkeler 
kendi dillerini öğretmek için çaba sarf etmektedir. Türkiye de devlet olarak Türkçeyi yabancılara öğretmek için gerek yurt içinde gerek Türkiye'de yaşayan yabancılara ya da eğitim gören öğrencilere, gerek yurt dışında Türkçe öğrenmek isteyenlere Türkçeyi ve Türk kültürünü öğretmek için büyük çaba harcamaktadır. Özellikle üniversitelerde okuyan yabancı öğrencilere yönelik değişik üniversitelerce Türkçe öğretim setleri hazırlanmıştır. Bu üniversitelerden biri de İstanbul Üniversitesidir. Bu üniversitenin hazırlamış olduğu İstanbul Yabancılar İçin Türkçe (IYİT) (C1) Ders Kitabı ile Almanca em neu Abschlusskurs (C1) Ders Kitabı karşılaştırılmıştır. Her iki kitap da üniversitelerin hazırlık bölümlerinde ve lisans bölümlerinde dil öğretiminde en çok tercih edilen kitapların başında gelmektedir.

Her dilin kendine özel atasözleri, deyimleri, nüktelerinin olması ve bunların bir başka dile aktarılmasındaki zorluklar, her dilin ayrı bir inanç yapısının, bakış açılarının, ayrı bir imkânlar ve yönelişler dünyasının eseri ve aynası olduğunu göstermektedir [...] Kültür ne ise, dil de odur. Kültürün ilgi alanları ne yönde ise, dil de o yönde zenginleşmiştir. Aynı durum ve davranış, farklı dillerde farkh kelimelerle ifade edilir (Kayayerli,1992:122-123 akt. Ünalan, 2014: 17). Ders kitapları hazırlanırken metinler seçilirken özellikle deyim, atasözü, kalıplaşmış ifadelere, hedef dilin edebiyatından seçme hikâyeler, masallar, şarkılar, şiirler, vecizeler, coğrafi bilgiler, yemek, folklor, sanat vb. birçok kültür ögesine yer verilmelidir. Ancak bu şekilde dil öğrenen kişi dilin gerçek kullanımına şahit olabilir. Aksi takdirde dil öğretmek sadece dilbilgisi öğretmenin ötesine geçememektedir. Ancak bu metinler hazırlanırken dil seviyesi göz önünde bulundurulmalı ve temel seviyeden (A1-A2) orta seviye (B1B2)'den ileri seviyeye (C1- C') kadar metinlerin zorluk derecesine göre düzenlenmelidir. Basitten zora doğru bir seçimle yapılmalıdır. (A1-A2) seviyesinde dil öğrenenler derin anlam ifade eden deyim ve atasözlerini anlamakta güçlük çekeceklerinden bu seviyede mümkünse daha somut, çevirisi kolay yapılabilen deyim, atasözü veya kalıplaşmış ifadeler tercih edilmelidir.

Alan yazın incelendiğinde farklı kültürlerin karşılaştırılmasından ziyade tek dilin öğretiminde kullanılan kaynak kitaplardaki kültür aktarımları incelendiği görülmektedir. Örneğin Dang. T. C. T. \& Seals, C. (2016) dil kullanımımızın büyük ölçüde kültür, iletişimciler arasındaki ilişkiler, dil stilleri ve ulusal dil politikaları gibi birçok sosyal faktöre bağlı olduğunu, bu nedenle, dil öğretmenleri ve öğrencilerinin dilin toplumbilimsel yönlerini dikkate almalarının esas olduğunu belirtmektedir. Litz (2002) ELT materyallerinin (ders kitaplarının) birçok dil sınıfında çok önemli bir rol oynamakta olduğundan, son yıllarda ortaya çıkan diğer konular arasında ders kitabı tasarımı ve pratiklik, metodolojik geçerlilik, ders kitaplarının yenilikteki rolü, materyalleri dilin temsili ve cinsiyetin uygunluğu açısından temsil, konu ve kültürel bileşenlerin önemli olduğundan bahsetmektedir. Prodromou (1998) ve Alptekin (1993) gibi diğer teorisyenler, ders kitaplarında dil öğretiminde bir araç olarak hedef dil kültürünün bir dili kültürel tabanına yerleştirmeden öğretmenin gerçekten mümkün olmadığını belirtmektedirler. Her iki yazara göre de böyle bir süreç, kaçınılmaz olarak öğrenenleri, kendilerini ait oldukları bir kültür içinde ifade etmeye zorlayacağını neredeyse hiç deneyimleri olmadığından ve bu durumun onları yabancılaşmaya, klişeleştirmeye ve hatta öğrenmeye isteksiz yapacağını veya direnç göstereceklerini ifade etmektedirler. Benzer şekilde, iltifatlara verilecek cevaplar da kültürlerarası iletişimde sorunlara neden olabileceğinden, çünkü farklı kültürlerin farklı tepki türlerini kabul etme eğiliminde olduklarından bahsedilmektedir (Nguyen: 2011). İletişimsel ders kitaplarında tüm etkinlikler ve beceriler günlük dilin söylemsel örnekleri etrafında dönerken, kültürlerarası olanlar ise güncel kültürle ilgili pek çok gerçeklik ve varsayımla birlikte günlük dilin örnekleri hedefteki görüşler ve konuşmacıların yerel kültürleri etrafında dönmektedir (Arıkan: 2008). ve aynı zamanda ders kitabı çoğunlukla kültürlerarası bilgi-şehir ve tarihi yerler- yerine hayatın farklı yönlerine ve perspektiflerine odaklanmalıdır (Atar \&Erdem: 2020). Yabancı dil öğretimi aynı zamanda o dilin kültürünün de öğretimidir. Dil ve toplum birlikte gelişip 
şekillendiği için yabancı bir dili gerçek anlamda öğrenmek, anlamak ve konuşmak o toplum gibi düşünebilmeyi gerektirmektedir. Bu da o dili şekillendiren kültürü öğrenmekle mümkündür (Memiş: 2016). Dil öğretiminde temel bir araç olan ders kitapları, dil öğretimiyle birlikte kültürün öğretimi hususunda önemli bir görev üstlenmektedir. Kitaplarda, Türk bayramlarından, gelenek ve göreneklerinden, önemli şair ve din adamlarından, liderlerden bahsedilmiştir. Kültürel birçok ögeye yer verilmiştir (Erdem \&Gün\& Karateke: 2015).

Yılmaz ( 2012) Yedi İklim Türkçe Öğretim seti B1 ve B2 düzeyi ders kitapları kültür aktarımı açısından incelendiğinde, içeriğinde hedef kültür olan Türk kültürünün öğrencilere farklı yönleriyle sunulan birçok öge içerdiği, bunun yanı sıra ders kitaplarında Türk kültürü dışında farklı kültürel unsurlarında yer aldığı görülmüş̧tür. Demir \&Açı (2011) Kültür aktarımı yapmak adına bütün kültürel unsurların verilmesi daha doğrusu günümüzde işlevine az rastlanan kültürel unsurların ya da kendi içinde bile çelişen kültürel unsurların günümüz şartlarında olmasına dikkat edilmelidir. Bu anlamda Türkçenin ve Türk kültürünün zenginliğinin en önemli göstergesi atasözleri ve deyimlerdir. Türkçe öğretiminde öğrenme alanları, okuma, yazma ve konuşma eğitiminde, dil öğretiminde vazgeçilmez öneme sahiptir (Bulut: 2013). Dil sadece kültürün önemli bir parçası değil aynı zamanda kültürün aktarıcısıdır. Bu nedenle yabancı dil öğretiminde kültürel ögelerin aktarılması dil öğrenme sürecini olumlu yönde etkiler. Bu görüşten hareketle, yabancı dil olarak Türkçe öğretiminde Türk kültürünü içeren ögelerin ders ortamına aktarılması gerekmektedir (Bölükbaş \&Keskin: 2010).

\section{Yöntem}

$\mathrm{Bu}$ çalışmada doküman incelemesi yöntemi kullanılmıştır. Doküman incelemesi, araştırılacak konular hakkında bilgi içeren yazılı materyallerin analizini kapsar (Yıldırım ve Şimşek, 2008). Seçilen materyaller IYİT Ders Kitabı (C1) ile Almanca em neu Abschlusskurs Deutsch als Fremdsprache (C1) Ders Kitabıdır. Sadece bu iki kitapta geçen metinler kültürlerarası yaklaşım açısından kaynak olarak ele alınmıştır. IYİT Ders Kitabı 12 üniteden, Almanca em neu Ders Kitabı ise 10 üniteden oluşmaktadır. Bu metinlerde geçen atasözü, deyim, vecize, argo ifadeler ve kalıplaşmış sözler karşılaştırılarak, sayısal olarak hangi kitapta kaç adet kültürel ögeye yer verildiği tespit edilmeye çalışılmıştır. Son olarak ünitelerde geçen konu başlıklarının birbirine eşdeğer olup olmadığına bakılmıştır.

\section{1. İstanbul yabancılar için Türkçe ders kitabının (C1) ünitelerinin yapısı}

IYİT Ders Kitabı 12 üniteden, her ünite de A, B, C bölümlerinden oluşmaktadır. Her ünitenin giriş sayfası üniteyle bağlantılı, Türkiye hakkında bilgi sunan resimlerden oluşmaktadır. Ünitelerin A,B,C bölümlerinde önce okuma sonra "Ya siz?”, ardından da konuşma bölümü yer almaktadır. A,B,C bölümlerinin hepsinde aynı sıra takip edilmektedir. Konuşma bölümünden sonra ise kültürden kültüre bölümleri vardır.

Kültürden Kültüre bölümünde kültürlerarası farkındalığı arttırmak amacıyla, kültürden kültüre değişen çeşitli konular hakkında bilgi veren metinlerden oluşmaktadır. Sözün Özü bölümünde ünitenin konu alanına ilişkin tarihteki önemli kişilerin sözleri ve çeşitli atasözleri bulunmaktadır. Medeniyetimize Yön Verenler bölümünde Türk ve İslam kültürü için önemli olan edebiyatçıların hayatları ve eserlerinden çeşitli bölümler sunulmaktadır. Neler Öğrendik bölümü, öğrencinin öğrendiği dilbilgisi, ünitenin konusuna ait kelime alıştırmaları vb. etkinlikleri içeren bir tekrar bölümüdür. Öz değerlendirme bölümünde, her bir ünite sonunda öğrenciden beklenen beceriler yer almaktadır. 
Ünite alt başlıkları, seçilen konular ve ele alınan dilsel yapılar incelendiği zaman hem Türk kültürüne hem de evrensel kültüre ait ögelerin varlığından söz edilebilir. Ayrıca ünitelerin Türk kültürünü yansıtan görsellerle desteklendiği görülmektedir.

\subsection{Em neu Abschlusskurs Deutsch als Fremdsprache (C1) kitabının ünite yapısı}

On üniteden oluşan kitabın her ünitesinin giriş sayfasında bir görsele yer verilmiştir. 3. ünite istisna olmak kaydıyla (1 adet) her ünitede iki adet okuma metni mevcuttur. Öğrencilerin yazılı metinler aracılı̆̆ıyla Alman kültürü ve Alman diline ait bilgi edinmesi sağlanmaktadır. Üniteler ağırlıklı okuma olmak üzere dinleme-yazma-konuşma-dilbilgisi ve kelime bölümlerinden oluşmaktadır. Kitap genel olarak değerlendirildiği zaman evrensel kültürün ön planda olduğu görülmektedir. Kültürel ögelerin yer aldığı ayrı bir bölüm yoktur ancak bu ögelere metinler içerisinde yer verilmiştir.

\section{Bulgular ve yorum}

Bu çalışmada elde edilen analizlerle ortaya çıkan sonuç aşağıdaki tablolarda da görüleceği üzere IYİT (C 1) Ders Kitabında em neu (C 1) Ders Kitabına göre daha fazla kültürel ögelere yer verildiğidir. IYİT Ders Kitabında kültürel ögelerin yeterli olduğunu söylemek mümkündür.

\section{4.İstanbul yabancılar için Türkçe (C1) ders kitabında yer alan ünite bazında geçen kültürel unsurlar}

I.Y.İ.T. Ders Kitabında yer alan kültürel unsurlar 4 temel dil becerisi altında sinıflandırılarak aşağıdaki tabloda verilmiştir.

\begin{tabular}{|c|c|}
\hline Ünite sıra no ve sayfa no & Ünitenin adı \\
\hline Ünite 1 (S. 9) & Öyle Bir Geçer Zaman ki \\
\hline Giriş Sayfası Resmi & $\begin{array}{l}\text { İzmir Saat Kulesi } \\
\text { Isaac Newton’un resmi }\end{array}$ \\
\hline Üniteye Hazırlık Sorusu (S. 10) & $\begin{array}{l}\text { Balzac’ın “Zaman öldürmek en pahalı harcamadır” sözünden ne } \\
\text { anlıyorsunuz diye sorulmaktadır. }\end{array}$ \\
\hline Okuma Metni A (S. 10) & $\begin{array}{l}\text { İlk okuma metninde "Saatin icadı" konusu ele alınmakta ve } \\
\text { Sümerlerden bahsedilmektedir. Aynı metin içinde "kum } \\
\text { saatinden” bahsedilmekte ve kum saatini ilk defa Avrupalıların } \\
\text { kullandığı belirtilmektedir. "Su saatlerini” ise ilk kullananların } \\
\text { Misırlllar olduğu vurgulanmaktadır. }\end{array}$ \\
\hline Ya siz? (S. 12) & $\begin{array}{l}\text { "Mekanik ya da elektronik saatler icat edilmeden önce sizin } \\
\text { ülkenizde hangi saat türlerinin kullanıldığını biliyor musunuz? } \\
\text { Daha önce metindeki saatlerden görüp zamanı nasıl gösterdiğini } \\
\text { anlamaya çalısstınız mı?" diye sorular sorarak saatler konusunda } \\
\text { öğrencinin bir karşllaştırma yapması istenmiştir. }\end{array}$ \\
\hline Dinleme A (S. 15) & $\begin{array}{l}\text { Dünyada en çok kullanılan takvimlerin hangileri olduğu } \\
\text { sorulmaktadır. Miladi takvim ile hicri takvim hakkında bilgi } \\
\text { verilmiştir. Karşlaştırma yapılmıştır. Ay yll, güneş yllı } \\
\text { anlatılmıştır. Türklerin kullandıkları en eski takvimin ne } \\
\text { olduğundan, ilk Babil takviminden, Mısırlıların gelisstirdikleri } \\
\text { takvimden bahsedilmektedir; Mayaların da zaman kaydı } \\
\text { tuttukları bilinmekteydi denilmektedir. Modern takvimlerin Jül } \\
\text { Sezar tarafindan kullanıma sokulduğu belirtilmistir. Bu takvim } \\
\text { 8. yüzyllda daha sonra İmparator Augustus tarafından } \\
\text { geliştirildiği vurgulanmaktadır. }\end{array}$ \\
\hline
\end{tabular}




\begin{tabular}{|c|c|}
\hline Yazma A (S. 15) & $\begin{array}{l}\text { "Ülkenizde hangi takvimi kullanıyorsunuz? Bu takvimin ortaya } \\
\text { çıkış hikâyesini” yazmaları istenmektedir. }\end{array}$ \\
\hline Dinleme B (S. 2o) & $\begin{array}{l}\text { İstanbul'u yansıtan bir resim vardır. Özdemir Asaf’ın “Olmak } \\
\text { İsterdim” adlı şiirine yer verilmiştir. Mihrabat Korusu'ndan, } \\
\text { Çamlıca'dan ve Marmara'dan bahsedilmektedir. }\end{array}$ \\
\hline Konuşma (S. 20) & $\begin{array}{l}\text { Zaman kavramıyla ilgili altı aT } 6 \text { adet Türk atasözü verilmiş ve } \\
\text { öğrencilere, bunlardan ne anladıkları sorulmaktadır. Bu } \\
\text { atasözleri: } \\
\text { “Terazi tartıyla, her şey vaktiyle ölçülür” - "Vakit nakittir" - } \\
\text { "Demir tavında dövülür” -“Vakitsiz öten horozun başını } \\
\text { keserler”- Geçti Bor'un pazarı sür eşeği Niğde’ye” -Ağaç yaşken } \\
\text { eğilir” atasözleridir. }\end{array}$ \\
\hline Okuma B (S. 21-22) & $\begin{array}{l}\text { Albert Einstein'ın, Edison'un, Graham Bell'in ve Isaac } \\
\text { Newton'un çocukluklarından bahsedilmektedir. }\end{array}$ \\
\hline Dilbilgisi (S. 24) & $\begin{array}{l}\text { Dilbilgisi bölümünde 1950'li 6o'lı yıllarda İstanbul'da kullanılan } \\
\text { taksi dolmuşlardan birinin resmi vardır. Diğer dilbilgisi } \\
\text { bölümlerinde böyle bir kültürel ögeye rastlanmamıştır. Sadece } 1 \text {. } \\
\text { ünitede böyle bir kültürel unsur mevcuttur. }\end{array}$ \\
\hline Dinleme C (S. 25) & $\begin{array}{l}\text { Nobel edebiyat ödülü sahibi John Nash’ın resmi vardır. } \\
\text { Kendisiyle } 2012 \text { yılında İstanbul'da yapılmış bir röportaja yer } \\
\text { verilmiştir. }\end{array}$ \\
\hline Yazma B (S. 25) & $\begin{array}{l}\text { “Ülkenizin en ünlü bilim adamı kimdir? Araştıralım ve yazalım” } \\
\text { konusu verilmiştir. }\end{array}$ \\
\hline Kültürden kültüre (S. 26) & $\begin{array}{l}\text { Birinci bölümde } 12 \text { hayvanlı Türk takviminden } \\
\text { bahsedilmektedir. }\end{array}$ \\
\hline Sözün özü (S. 26) & $\begin{array}{l}\text { “Sözün Özü” adlı bölümde beş adet ünlüden veciz sözler ile } \\
\text { Hz.Muhammed’in bir hadisi yer almaktadır. Hepsinin ortak } \\
\text { noktası "zaman” kavramıdır. }\end{array}$ \\
\hline Medeniyetimize Yön verenler (S. 27) & Cengiz Dağcı'nın “Yansılar I” adlı eserinden bahsedilmektedir. \\
\hline
\end{tabular}

Tablo 1: IYYITT ders kitabı 1. ünitede geçen kültürel unsurlar.

1. ünite incelendiğinde Türk kültürüne ait resim, takvim, atasözü, vecize ve bir edebiyatçıdan Özdemir Asaf'tan bahsedilmektedir. İzmir'deki saat kulesine ve İstanbul'a ait bir resme, eski taksi dolmuş resimlerine yer verilmiştir. Türklerin kullandıkları en eski takvimin ne olduğundan bahsedilmektedir. Ayrıca yabancı kültürlere ait vecizelerden, medeniyetlerden Sümerlerden, Avrupalılardan, Misırlılardan, Babillerden, Mayalardan, ünlü kişilerden Jül Sezar'dan, İmparator Agustus’tan, Albert Einstein'dan, Edison'dan, Graham Bell'den, Isaac Newton'dan ve John Nash'tan bahsedilmektedir. Birinci ünitede hem Türk kültürüne ait unsurlara hem de yabancı kültürlere ait unsurlara yer verilmiştir. Ancak yabancı kültüre ait unsurlara özellikle yabancı medeniyetlerden daha fazla söz edilmiştir.

\begin{tabular}{|l|l|}
\hline Ünite sıra no ve sayfa no & Ünitenin adı \\
\hline Ünite 2 (S. 32) & Aşk Olsun. \\
\hline Giriş Sayfası Resmi (S. 31) & $\begin{array}{l}\text { Konya'daki Mevlana Camisi’nin, Mevla'nın ve semazenlerin } \\
\text { resimleri vardır. }\end{array}$ \\
\hline Üniteye Hazırlık Sorusu (S. 37) & $\begin{array}{l}\text { Ünlü âşılklar başlığı altında hazırlık çalışması olarak 10 ünlü } \\
\text { tarihi kişiliğin resmi verilmiştir. Ve ögrencilere; bunlardan } \\
\text { hangilerinin tarihi aşklarını bildikleri sorulmaktadır. Bu ünlüler: } \\
\text { Hürrem Sultan- Kee Voos- Latife Hanım- Kleopatra- Marilyn } \\
\text { Monreo- Mustafa Kemal Atatürk- Marcus Antonius- Arthur } \\
\text { Miller- Vincent van Gogh- Kanuni Sultan Süleyman'dır. }\end{array}$ \\
\hline
\end{tabular}




\begin{tabular}{|c|c|}
\hline Okuma Metni A (S. 38) & $\begin{array}{l}\text { Ünlü âşıklar ve mektupları verilmiştir. Bu metinlerde Aragon ve } \\
\text { Elsa'nın Dostoyevski ve Maria'nın, Einstein ve Mileva'nın, Furuğ } \\
\text { Ferruhzad ve Perviz'in, Nazım ve Piraye'nin, Kafka ve Milena'nın } \\
\text { aşklarından bahsedilmektedir. }\end{array}$ \\
\hline Dinleme A (S. 36) & Leyla ve Mecnun'undan bahsedilmektedir. \\
\hline Yazma (S. 36) & $\begin{array}{l}\text { Mevlana'nın aşkı nasıl tanımladığı belirtilmekte ve } \\
\text { öğrencilerden bu tanımdan ne anladıklarını yazmaları } \\
\text { istenmektedir. }\end{array}$ \\
\hline Dinleme B (S. 40) & Yusuf ile Züleyha'dan bahsedilmektedir. \\
\hline Konuşma A (S. 40) & $\begin{array}{l}\text { Sevgi sözcüğü ile ilgili beş Türk atasözü verilmiş ve onlar } \\
\text { hakkında konuşmaları istenmektedir. } \\
\text { "Kalp kalbe karşıdır"- "Gülü seven dikenine katlanır”- "Her } \\
\text { yiğidin gönlünde bir aslan yatar”- "Gönül bir sırça saraydır, } \\
\text { kırılırsa yapılmaz"- "Gönül kimi severse güzel odur”. }\end{array}$ \\
\hline Dinleme C (S. 45) & Mevlana ile Şems'ten bahsedilmektedir. \\
\hline Konuşma B (S. 45) & $\begin{array}{l}\text { On ünlü kişinin aşk üzerine söyledikleri vecizelerden hangisine } \\
\text { katıldıkları sorulmaktadır. Nedenini açıklamaları istenmiştir. } \\
\text { Bunlar: } \\
\text { 1.Aşkı, aşktan başka bir şey söndürmez. (Mevlana) } \\
\text { 2.Aşkı akılla yenmek mümkün değildir. (Gançarov) } \\
\text { 3.Aşk, iki iken bir olmak demektir. (Victor Hugo) } \\
\text { 4.Hakiki aşk ızdırap çeker ve sessizdir. (Oscar Wilde) } \\
\text { 5.Aşk ve öksürük saklanmaz. (George Herbert) } \\
\text { 6. İnsan kalbindeki gerçek aşk, dörtnala giden bir attır, ne } \\
\text { dizginden anlar, ne ses dinler. (Confucius) } \\
\text { 7. İnsan ne kadar büyük ruhlu olursa, aşkı o kadar derin bir } \\
\text { şekilde duyar. (Leonardo da Vinci) } \\
\text { 8. Gerçek aşkta ne vefa vardır ne cefa. (Mevlana) } \\
\text { 9. Aşk, gözle değil, ruhla görülür. (William Skakespeare) } \\
\text { 10. Aşk bir güneşe benzer, âşık olmayan gönül, bir katı taşa } \\
\text { benzer. (Yunus Emre) }\end{array}$ \\
\hline Kültürden kültüre (S. 46) & $\begin{array}{l}\text { Evlilik geleneklerinden bahsedilmektedir. Türkiye'den (tuzlu } \\
\text { kahve), Hindistan'dan (damada ayak banyosu) ve Çin'den (ayın } \\
\text { 15’i uğursuz saylır) örnekleri verilmiştir. }\end{array}$ \\
\hline Sözün özü (S. 46) & $\begin{array}{l}\text { “Aşk olsun” deyiminin sizin kültürünüzde bir karşılı̆̆ı var mı? } \\
\text { diye sorulmaktadır. }\end{array}$ \\
\hline Medeniyetimize Yön verenler (S. 47) & Cengiz Aytmatov'dan bahsedilmektedir. \\
\hline
\end{tabular}

Tablo 2: IYYiT ders kitabı 2. ünitede geçen kültürel unsurlar

2. ünite incelendiğinde Türk kültürüne ait resimler verilmiş, ünlü kişilerden, atasözlerinden, vecizelerden, evlilik geleneklerinden bahsedilmektedir. Yabancı kültüre ait ünlü kişilerden, vecizelerden, evlilik geleneklerinden bahsedilmektedir. Her iki kültüre ait gerek kişiler gerek vecizeler gerekse gelenekler eşit derecede ele alınmış ve karşılaştıılmıştır. 


\begin{tabular}{|c|c|}
\hline Ünite sıra no ve sayfa no & Ünitenin adı \\
\hline Ünite 3 (S.49) & İşini şansa bırakma. \\
\hline Giriş Sayfası Resmi (S. 49) & $\begin{array}{l}\text { Adıyaman Nemrut Dağı } \\
\text { Altta küçük resimlerde tavla kutusu, havaya para saçan bir } \\
\text { adam, bankta düşünen bir adam ve elmas gerdanlık vardır. }\end{array}$ \\
\hline Üniteye Hazırlık Sorusu (S. 50) & $\begin{array}{l}\text { Hazırlık çalışması bölümünde şansla ilgili deyim ve ifadeler } \\
\text { mevcuttur. } \\
\text { “Şansım yaver gitti”, “Bizde şans mı var?”, SSans bana güldü”, } \\
\text { "Şansım olsaydı bu hale düşmezdim”, "Bizde de ne şans var”, } \\
\text { "Şanssızım tekiyim”. }\end{array}$ \\
\hline Okuma Metni A (S. 50-51) & $\begin{array}{l}\text { Piyangodan büyük ikramiye kazanmış insanların daha sonra } \\
\text { düsstükleri halleri anlatan değişik hikâyelere yer verilmiștir. } \\
\text { Osman Kaplan Denizli'den, Adanalı Cem Postacı, Denizli'den } \\
\text { Mehmet Sarığlu, Jack Whittaker, Bill Bob Harrell Texas'tan. }\end{array}$ \\
\hline Okuma B (S. 55-56) & $\begin{array}{l}\text { Okuma bölümünde kısaca satrancın ve tavlanın tarihine } \\
\text { değinilmiştir. }\end{array}$ \\
\hline Yazma (S. 61) & $\begin{array}{l}\text { Hüma Kuşundan bahsedilmiştir yani bir efsaneden. Bir adı da } \\
\text { devlet kuşudur. }\end{array}$ \\
\hline Dinleme (S. 61) & $\begin{array}{l}\text { “Dünyanın en şanssızı ile en şanlısını” anlatan bir metin } \\
\text { verilmiştir. Dünyanın en şanslı insanı Hırvatistan'dan emekli bir } \\
\text { öğretmenden bahsedilmektedir. Adam yedi büyük felaketten } \\
\text { kurtulmuştur. En şanssız insanı ise Bernard Ancheriaux. 150 } \\
\text { kaza geçirmiş ama yine de kurtulmuştur. }\end{array}$ \\
\hline Konuşma A (S. 54) & $\begin{array}{l}\text { Konuşma bölümünde aşağıdaki vecizelerden ne anladıkları } \\
\text { sorulmuştur. } \\
\text { Kendi kendilerine yardım etmeyenlere talih bile yardım edemez. } \\
\text { (Rochefoucauld) } \\
\text { Talih, çalışmak istemeyenlere yardım etmez. (Sophokles) } \\
\text { Her güne hayatının en güzel günü olması için şans ver. (Mark } \\
\text { Twain) } \\
\text { Talihsizliklerin suçu kendimizdedir ancak bunu yaşlandıktan } \\
\text { sonra anlarız. (D. Carneige) } \\
\text { Talih bize haberci göndermez. (Oscar Wilde) } \\
\text { Şans bir uğraşının eseridir. (Branch Rickey) }\end{array}$ \\
\hline Üniteye Hazırlık B (S. 55) & $\begin{array}{l}\text { Beş adet deyimle bunların anlamları verilmiştir ve bunların } \\
\text { eşleştirilmesi istenmektedir. } \\
\text { “Talih yüzüne gülmek"- "Feleğe küsmek"- "Şansı dönmek”- “İşi } \\
\text { rast gitmek”- "Uğur getirmek”. }\end{array}$ \\
\hline Konuşma B (S. 61) & $\begin{array}{l}\text { Konuşma bölümünde verilen atasözleri hakkında konuşmaları } \\
\text { istenmiştir. } \\
\text { “Güzellerin talihi çirkin olur”. } \\
\text { “Talihsiz hacıyı deve üstünde yılan sokar”. }\end{array}$ \\
\hline Kültürden kültüre (S. 62) & $\begin{array}{l}\text { Kültürden kültüre bölümünde dört yapraklı yoncanın şans } \\
\text { getirdiğine dair bir anlatım vardır. Baykuş örneği verilerek } \\
\text { onların da uğursuzluk getirdiği anlatılmıştır. } \\
\text { Sizin ülkenizde de uğurlu ve uğursuz olduğuna inanılan nesneler } \\
\text { veya canlılar var mı? Anlatmaları istenmiştir. }\end{array}$ \\
\hline Sözün özü (S. 62) & $\begin{array}{l}\text { Sözün özü bölümünde dört vecize verilmiş ve bunlar hakkında } \\
\text { konuşmaları istenmiştir. } \\
\text { Talihi olanın horozu da yumurtlar. (Napolyon) } \\
\text { Aklını iyi kullananlara talih yardım eder. (Euripides) }\end{array}$ \\
\hline
\end{tabular}




\begin{tabular}{|l|l|}
\hline & $\begin{array}{l}\text { Hayatınızın sonuna kadar yaşamadıkça talihinizden şikâyet } \\
\text { etmeyin. (Çehov) } \\
\text { Yiğidin talihi yanındadır. (Terence) }\end{array}$ \\
\hline Medeniyetimize Yön verenler (S. 63) & $\begin{array}{l}\text { Medeniyete yön verenler bölümünde M. Akif Ersoy'dan } \\
\text { bahsedilmiştir. } \\
\text { Bir Gece adlı şiiri örnek olarak verilmiştir. }\end{array}$ \\
\hline
\end{tabular}

Tablo 3: IYYİT ders kitabı 3. ünitede geçen kültürel unsurlar

3. ünite incelendiğinde Türk kültürüne ait resim, deyim ve ifadeler, piyangodan para kazanmış ve gazetelerde haber konusu olmuş kişilerden, vecizelerden, atasözlerinden, inanışlardan ve şair M. Akif Ersoy'dan bahsedilmektedir. Yabancı kültüre ait gazetelerde haber konusu olmuş kişilerden, vecizelerden bahsedilmektedir. Bu ünitede Türk kültürüne ait ögeler oldukça fazladır. Diğer kültürlerde olmayan bazı batıl inançlardan bahsedilmiştir. Örneğin; baykuşun ötmesinin uğursuzluk getirdiğinden, Hüma kuşundan (başına konduğu kimseye mutluluk getirdiğine inanılan talih kuşu), dört yapraklı yonca şans ilişkisinden ve tavladan bahsedilmektedir.

\begin{tabular}{|l|l|}
\hline Ünite sıra no ve sayfa no & Ünitenin adı \\
\hline Ünite 4 (S. 65) & Bir Maruzatım Var. \\
\hline Giriş Sayfası Resmi (S. 65) & $\begin{array}{l}\text { Pamukkale travertenleri verilmiştir. Altta ise küçük resimlerde } \\
\text { adaletin simgesi terazi resmi, büroda iş hayatından bir kesit, eski } \\
\text { arzuhalcilerden bir resim ve iş görüşmesine dair bir resim vardır. }\end{array}$ \\
\hline Okuma Metni A (S. 66) & $\begin{array}{l}\text { Arzuhalden dilekçeye adlı okuma metninde dilekçenin geçirdiği } \\
\text { tarihi evreler anlatılmıştır. }\end{array}$ \\
\hline Dinleme A (S. 68) & Derdini anlat Marko Paşa'ya adlı bir metin vardır. \\
\hline Okuma B (S. 72) & $\begin{array}{l}\text { Okuma metninde Fatih Sultan Mehmet ile Rum Mimar arasında } \\
\text { mahkemede geçen bir olay anlatılmaktadır. }\end{array}$ \\
\hline Kültürden kültüre (S. 76) & $\begin{array}{l}\text { "Kültürden kültüre” bölümünde ise Türkiye'de saygı ile ilgili } \\
\text { ifade ve davranışlara, Kore'de saygı ve uygun hitaplara, } \\
\text { Fransa'da saygıa örnek verilmiştir. }\end{array}$ \\
\hline Sözün özü (S. 76) & $\begin{array}{l}\text { Hz. Ebu Bekir'in “Şikâyet, zayıfların silahıdır” sözü ile J.J. } \\
\text { Rousseau'nun “Çok şikâyet edenler, çok şikâyet edilenlerdir” } \\
\text { sözlerine yer verilmiştir. }\end{array}$ \\
\hline Medeniyetimize Yön verenler (S. 75) & $\begin{array}{l}\text { Medeniyetimize yön verenler bölümünde Sezai Karakoç } \\
\text { tanıtılmıştır. } \\
\text { Mona Rosa adlı şiiri örnek olarak verilmiştir. }\end{array}$ \\
\hline
\end{tabular}

Tablo 4: IYİT ders kitabı 4. ünitede geçen kültürel unsurlar

4.ünitede Türk kültürüne ait resim, tarihi şahsiyetler (Marko Paşa: Derdini Marko Paşa'ya anlat deyimi. Anlamı: Yakınmanı dinleyecek kimse yok (Aksoy, 1988: 713), arzuhalciden (para karşllğında dilekçe, mektup vb. yazan kimse) yazar ve şairden, Türkiye'de saygıdan bahsedilmektedir. Yabancı kültüre ait sadece geleneklerle ilgili olarak Kore'de ve Fransa'da saygıdan bahsedilmektedir. Bu ünitede Türk kültürüne ait unsurlardan daha fazla bahsedilmiştir. 


\begin{tabular}{|c|c|}
\hline Ünite sıra no ve sayfa no & Ünitenin adı \\
\hline Ünite 5 (S. 79) & Film Şeridi Gibi. \\
\hline Giriş Sayfası Resmi (S. 79) & $\begin{array}{l}\text { Kapadokya'ya ait büyük bir resim vardır. Altta küçük resimlerde } \\
\text { sinema ile ilgili resimler vardır. Bir afiş, bir yönetmen, } \\
\text { subliminal mesajları tasvir eden bir resim verilmiştir. }\end{array}$ \\
\hline Okuma A (S. 80-81) & Lumiere Kardeşler \\
\hline Okuma B (S. 85) & Okuma metninin konusu "Susuz Yaz" adlı Türk sinema filmidir. \\
\hline Ya siz (S. 87) & $\begin{array}{l}\text { "Sizin ülkenizde uluslararası bir festivalde ödül alan bir film var } \\
\text { mı?". Anlatmaları istenmektedir. }\end{array}$ \\
\hline Dinleme A (S. 89) & Yazar ve senarist Sulhi Dölek'le yapılan röportaja yer verilmiştir. \\
\hline Okuma C (S. 90-91) & Yabancı ülkelerde yayınlanan Türk dizilerine yer verilmiştir. \\
\hline Dinleme B (S. 94) & Yazlık sinemalardan bahsedilmiştir. \\
\hline Kültürrden kültüre (S. 95) & $\begin{array}{l}\text { Türkiye'de verilen en prestijli sinema ödüllerinden "Uluslararası } \\
\text { Antalya Altın Portakal Film Festivaline” yer verilmiştir. Sonra } \\
\text { "OSCAR Akademi Ödülleri ve Fransa Cannes Film Festivali” } \\
\text { tanıtılmıştır. }\end{array}$ \\
\hline Sözün özü (S. 96) & $\begin{array}{l}\text { Sinema sanatıyla ilgili üç vecizeye yer verilmiştir. } \\
\text { Film yapmak, birçok kereler yaşamak için bir şanstır. Robert } \\
\text { Altman } \\
\text { Sinema, filme alınmış tiyatrodur. Robert Breson } \\
\text { Eski filmlere karşı kendimi bir baba gibi hissederim. } \\
\text { Çocuklarınızı dünyaya getirirsiniz, sonra onlar büyür ve sizi terk } \\
\text { ederler. Zaman zaman birlikte olursunuz ve onları yeniden } \\
\text { görmek sizin için her defasında büyük bir keyif olur. } \\
\text { Michelangelo Antonioni. }\end{array}$ \\
\hline Medeniyetimize Yön verenler (S. 96) & $\begin{array}{l}\text { Yazar ve şair Necip Fazıl Kısakürek anlatılmıştır. Çile şiirinden } \\
\text { örnek verilmiştir. }\end{array}$ \\
\hline
\end{tabular}

Tablo 5: IYİT ders kitabı 5. ünitede geçen kültürel unsurlar

5. ünitede Türkiye'nin önemli turizm merkezlerinden Kapadokya'ya ait görsellere ve sinema ile ilgili resimlere yer verilmiştir. Ayrıca yazar ve senarist Sulhi Dölek ile yapılmış bir röportaja yer verilmiştir. Türk kültürüne özgü yazlık sinemalardan (1980'li yıllarda televizyonun sinemaya etkisi ortaya çımadan önce, Türkiye'de özellikle havaların ısınması ile birlikte genelde Mayıs'tan Eylül'e kadar çalıştırılan, tahta sandalyelerin perdenin önüne dizilmesi ile oluşturulmuş sinemalardır) (wikipedia.org.tr) bahsedilmektedir. Ayrıca "Susuz Yaz" filminden de (1964 Berlin Film Festivalinde Altın Ayı Ödülünü almış ilk Türk filmidir) bahsedilmektedir. Yabancı kültüre ait Fransa'da yapılan ünlü Cannes Film Festivalinden bahsedilmiştir. Sinema sanatıyla ilgili üç yabancı aktörün özdeyişine yer verilmiştir. Bu ünitede ağırlıklı olarak sinema sanatı konusu üzerinde durulmuştur. Bu konuyla ilgili görsellere, festivallere ve özdeyişlere yer verilmiştir. 


\begin{tabular}{|c|c|}
\hline Ünite sira no ve sayfa no & Ünitenin adı \\
\hline Ünite 6 (S. 99) & Bilgi Dünyası. \\
\hline Giriş Sayfası Resmi (S. 99) & $\begin{array}{l}\text { İzmir Selçuk'a bağlı Efes’te bulunan Celsus Kütüphane } \\
\text { kalıntısının büyük bir resmi vardır. Altta küçük resimlerde } \\
\text { bilgisayar klavyesi, İstanbul Üniversitesinin giriş kapısının } \\
\text { resmi, bir bilgenin resmi vardır. }\end{array}$ \\
\hline Üniteye Hazırlık Sorusu (S. 10o) & $\begin{array}{l}\text { Mevlana’nın “Sevgide güneş gibi ol, dostluk ve kardeşlikte } \\
\text { akarsu gibi ol, hataları örtmede gece gibi ol, tevazuda toprak } \\
\text { gibi ol, öfkede ölü gibi ol, her ne olursan ol ya olduğun gibi ya da } \\
\text { göründüğün gibi ol” sözü verilmiş ve açılanması istenmiştir. }\end{array}$ \\
\hline Yazma (S. 103) & $\begin{array}{l}\text { Eflatun’un “İnsanoğlunun sizi en çok şaşırtan iki davranışı } \\
\text { nedir?” sorusuna vermiş olduğu cevapla ilgili bir kompozisyon } \\
\text { yazmaları istenmiştir. }\end{array}$ \\
\hline Hazırlık çalışması C (S. 107) & $\begin{array}{l}\text { Üç resim verilmiş ve bunların eşleştirilmesi istenmiştir. } \\
\text { Celsus kütüphanesi } \\
\text { İskenderiye kütüphanesi } \\
\text { British Museum kütüphanesi }\end{array}$ \\
\hline Ya siz? (S. 109) & “Ülkenizdeki üniversite sistemi nasıl?” Anlatmaları istenmiştir. \\
\hline Kültürden külttüre (S. 111) & $\begin{array}{l}\text { Dünyadaki üniversiteler başlı̆̆g altında Darulfünun, Nizamiye } \\
\text { Medreseleri, Kurtuba Üniversitesi, ve Keyruvan Üniversitesi } \\
\text { resimleriyle birlikte kısaca tanıtılmıştır. }\end{array}$ \\
\hline Medeniyetimize Yön verenler (S. 112) & Yazar Cemil Meriç anlatılmıştır. \\
\hline
\end{tabular}

Tablo 6: IYYITT ders kitabı 6. ünitede geçen kültürel unsurlar

6.ünitenin konusu bilgi olduğu için İzmir'de bulunan Celsus Kütüphanesinin, İskenderiye’de bulunan İskenderiye Kütüphanesinin ve Londra'da bulunan British Museum'un tarihinden bahsedilmektedir. Bilgiyle ilişkili olarak eğitimden de bahsedilmektedir. İstanbul Üniversitesi’nden eski adıyla Darülfünundan (II. Abdülhamit dönemimde 1900 yllında kurulmuştur), Nizamiye Medreselerinden (Büyük Selçuklu Devleti zamanında kurulan), Kurtuba Üniversitesinden (İspanya’da Endülüs Emevi devleti tarafından yapılan) ve Keyruvan Üniversitesinden (Fas'ın Fez şehrinde kurulan) üniversitelerden bahsedilmektedir. Ayrıca bilgi teknolojilerinden bahsedilmektedir. Bu ünitede hem yerli hem de yabancı kültüre ait unsurlara eşit derecede yer verilmiştir.

\begin{tabular}{|l|l|}
\hline Ünite sıra no ve sayfa no & Ünitenin adı \\
\hline Ünite 7 (S. 115) & Sanat Sanat İçindir. \\
\hline Giriş Sayfası Resmi (S. 115) & $\begin{array}{l}\text { Truva Atının heykeli verilmisstir. Altta küçük resimlerde ebru } \\
\text { sanatından bir örnek, ünlü tiyatrocu Yıldz Kenter'in resmi ve } \\
\text { bir adet yağlı boya tablosu verilmiştir. }\end{array}$ \\
\hline Dinleme A (S. 118) & İstanbul Modern Sanat Müzesi tanıtılmaktadır. \\
\hline Dinleme B (S. 122) & Ressam Setenay Alpsoy ile yapılmış bir röportaja yer verilmiştir. \\
\hline Okuma (S. 123) & $\begin{array}{l}\text { Geleneksel Türk el sanatlarından ebru sanatı, hat sanatı, tezhip } \\
\text { sanatı ve minyatür sanat dallarından bahsedilmektedir. }\end{array}$ \\
\hline Dinleme C (S. 125) & Ünlü tiyatrocu Yıldız Kenter tanıtılmışstır. \\
\hline Kültürden kültüre (S. 126) & İstanbul Kültür Sanat Vakfi tanıtılmıştır. \\
\hline Medeniyetimize Yön verenler (S.126) & Yazar ve şair Cemal Süreya anlatılııştır. \\
\hline Sözün özü (S. 127) & Sanat ile ilgili özlü sözler verilmiştir. \\
\hline
\end{tabular}




\begin{tabular}{|l|l|}
\hline & "Sanatsız kalmış bir milletin hayat damarlarından biri kopmuş \\
& demektir”. M. Kemal Atatürk. \\
& Tenkit kolay, sanat güçtür. Destouches. \\
& Sanatın vazifesi, tabiatı kopya etmek değil, tabiatı ifade \\
& etmektir. Balzac. \\
& Sanat, sanat içindir. Victor Cousin. \\
& Sanat kâinatın içindedir, sanatkâr bunu oradan çıarabilendir. \\
& AlbrechtDurer. \\
& Sanat, ekmek peşinde koşarsa alçalır. Aristophanes. \\
& Sanatçıy iki göz yetmez. Lamartine. \\
& Sanatçı, göz ve kulağını bize ödünç verir. İspanyol atasözü. \\
& Sanat uzun, hayat kısadır. Goethe. \\
& Sanat, taklidin bittiği yerde başlar. Oscar Wilde \\
& Bu özlü sözlerin açıllanması istenmiştir. \\
\hline
\end{tabular}

Tablo 7: IYYIT ders kitabı 7. ünitede geçen kültürel unsurlar

7. ünitenin konusu sanattır ve farklı sanat dalları tanıtılmıştır. Örneğin; ebru sanatı: Ebru, kitreyle yoğunlaştırılmış su üstünde, özel hazırlanmış boyalarla oluşturulan desenlerin kâğıt üzerine geçirilmesi yoluyla yapılan bir süsleme sanatıdır (wikipedia.org.tr).

Hat sanatı: Kaligrafi, yazı karakteri ve unsurları kullanılarak geliştirilen, sıklıkla dekoratif amaçla kullanılan bir el sanatı çeşididir (wikipedia.org.tr). Arap harfleri çevresinde oluşmuş güzel yazı yazma sanatıdır (hurriyet.com.tr). Tezhip sanatı: Tezhip Türk süsleme sanatlarından biridir. Kelime anlamı "Altınla süslemek"tir. Arapça tezhip; "altınlamak", "yaldızlama", "bezeme", yazma kitapların sayfalarına, hat levhalarına, murakkalara hatta tuğraların üst taraflarına altın tozu ve boya ile yapılan her türlü bezeme sanatıdır (kulturportali.gov.tr). Resim olarak Truva Atı, Ebru sanatıyla ilgili bir resim ve ünlü tiyatrocu Yıldız Kenter'in resimleri mevcuttur. Ayrıca İstanbul Modern Sanat müzesi ve İstanbul Kültür Vakfı tanıtılmaktadır. Şair ve yazar Cemal Süreya tanıtılmıştır. Sanat ile ilgili hem Türk hem de yabancı ünlü kişilerin söylemiş olduğu vecizelere yer verilmiştir. Bu ünitede ağırlıklı olarak Türk kültürüne ait el sanatları tanıtılmıştır.

\begin{tabular}{|c|c|}
\hline Ünite sura no ve sayfa no & Ünitenin adı \\
\hline Ünite 8 (S. 129) & Suç ve ceza. \\
\hline Giriş Sayfası Resmi (S. 129) & $\begin{array}{l}\text { Bir nehir resmi. Küçük resimlerde elleri kelepçeli bir insan, } \\
\text { hâkimlerin mahkemelerde duruşmanın başladığını ya da } \\
\text { bittiğini göstermek için kullandığı tokmak resmi verilmiştir. }\end{array}$ \\
\hline Ya siz? (S. 131) & Ülkenizdeki suç oranı ve ceza sistemi hakkında ne biliyorsunuz? \\
\hline Üniteye Hazırlık Sorusu (S. 133) & Değişik ülkelerde uygulanan cezalara örnekler verilmiştir. \\
\hline Dinleme A (S.135) & $\begin{array}{l}\text { Dostoyevski’nin “Suç ve Ceza” romanından kısa bir kesit } \\
\text { alınmıştır. }\end{array}$ \\
\hline Okuma (S. 136-137) & $\begin{array}{l}\text { Stephan King'in “Esaretin Bedeli” adlı eserinden kısa bir kesit } \\
\text { verilmiştir. }\end{array}$ \\
\hline Dinleme B (S. 138) & $\begin{array}{l}\text { Ömer Seyfettin'in “Kaşağı” adlı hikâyesinden bir bölüm } \\
\text { alınmıştır. }\end{array}$ \\
\hline Kültürden kültüre (S. 139) & $\begin{array}{l}\text { İlk kanunlara örnek verilmiştir. Eski Türk kanunları, } 12 \text { Levha } \\
\text { Kanunları, Hammurabi Kanunlarından bahsedilmektedir. }\end{array}$ \\
\hline Sözün özü (S. 139) & Adalet, hukuk ile ilgili vecizelere yer verilmiştir. \\
\hline
\end{tabular}




\begin{tabular}{|l|l|}
\hline & $\begin{array}{l}\text { Mal cimride, silah korkaklarda, karar da zayıllarda olursa düzen } \\
\text { bozuktur. Hz. Ebu Bekir. } \\
\text { Adalet hissi insanlarda doğuştan mevcuttur. Çiçero. }\end{array}$ \\
& $\begin{array}{l}\text { Hukuk ile medeniyet ve kültürleri arasında ahenk kuramayan } \\
\text { cemiyetler bedbahttıllar. Falih Rıfkı Atay. } \\
\text { Adalet kutup yıldızı gibi yerinde durur ve geri kalan her şey } \\
\text { onun etrafında döner. Konfüçyüs. }\end{array}$ \\
\hline Medeniyetimize Yön verenler (S. 140) & Hilmi Yavuz tanıtılmıştır. ”Aynalar ve Zaman” şiiri verilmiştir. \\
\hline
\end{tabular}

Tablo 8: İYİT ders kitabı 8. ünitede geçen kültürel unsurlar

8. ünitenin konusu adalet ve hukuktur ve konuyla ilgili olarak mahkeme salonu, hâkimlerin kullandığı tokmak ve elleri kelepçeli bir insan resmi kullanılmıştır. Ayrıca suç ve ceza konusunu işleyen yerli ve yabancı yazarların eserlerinden bahsedilmiştir. Dostoyevski'nin "Suç ve Ceza "Stephan King’in "Esaretin Bedeli” adlı eserlerinden kısa kesitler ile Ömer Seyfettin’in “Kaşağı” adlı eserinden bir bölüm alınmıştır. Tarihte yapılan ilk yazılı kanunlara örnekler verilmiştir. Eski Türk kanunlarından "Töre" adı verilen örfi hukuktan bahsedilmiştir. Bu hukukun üç kaynağının olduğu belirtilmekte, bunlar: halk, kurultay ve kağandır. Daha sonra 12 Levha Kanunlarından bahsedilmektedir. Roma İmparatorluğu dönemine ait ilk yazılı kanunlar olduğu Roma toplumundaki Patrici (soylular) ve Pleb (halk) arasındaki sınıf mücadelesi sonucu hazırlandığı belirtilmektedir. Daha sonra da Hammurabi Kanunlarından bahsedilmektedir. M.Ö. 1760 yılı civarında Babil Kralı Hammurabi tarafından Mezopotamya'da oluşturulan tarihin en eski yazılı kanunlarından biri olduğu vurgulanmaktadır. Son olarak adalet ve hukukla ilgili vecizelere yer verilmiştir. Şair ve yazar Hilmi Yavuz tanıtılmıştır.

\begin{tabular}{|c|c|}
\hline Ünite sıra no ve sayfa no & Ünitenin adı \\
\hline Ünite 9 (S. 143) & Hayata Gülümse. \\
\hline Giriş Sayfası Resmi (S. 143) & $\begin{array}{l}\text { Şanlıurfa Balıklı Göl’ün resmi verilmiştir. } \\
\text { Küçük resimlerde bir karikatür, değişik ülkelerden çocukların } \\
\text { resimleri ve stand up yapan ünlü bir komedyenin resmi } \\
\text { verilmiştir. }\end{array}$ \\
\hline Ya siz? (S. 145) & $\begin{array}{l}\text { "Sizin ülkenizde mizahın halk arasındaki popülerliği ne kadar?" } \\
\text { sorusu sorulmuştur. }\end{array}$ \\
\hline Dinleme A (S. 147) & Nasrettin Hoca'nın bir fikrası anlatılmıştır. \\
\hline Yazma (S. 151) & $\begin{array}{l}\text { Türkçede argoda kullanılan kelimelere örnekler verilmiş ve } \\
\text { bunlarla bir hikâye yazmaları istenmiştir. } \\
\text { Aparmak- Bas git- Damlamak- Dümen yapmak- Enselemek- } \\
\text { Hava basmak- Külyutmaz- Zokayı yutmak- Sinek avlamak- } \\
\text { Topuklamak- Anasının gözü- Bıçkın- Çıngar çıarmak- Delik- } \\
\text { Dikizlemek- Mandepsiye basmak- Postu deldirmek }\end{array}$ \\
\hline Okuma (S. 152) & Mizah ustası Hasan Kaçan tanıtılmıştır. \\
\hline Dinleme B (S. 154) & Ünlü bir komedyenle yapılmış bir röportaj vardır. \\
\hline Kültürden kültüre (S. 155) & $\begin{array}{l}\text { Dünya çocukları nasıl oyun oynadıkları konusunda Türkiye'den, } \\
\text { Japonya'dan ve İngiltere'den örnekler verilmiştir. }\end{array}$ \\
\hline Sözün özü (S. 155) & $\begin{array}{l}\text { Dostoyevski ve Victor Borges’ten veciz sözler verilmiştir. } \\
\text { Kaybolan gün hiç gülmeden geçen gündür. Dostoyevski. } \\
\text { Gülme iki insan arasındaki en kısa mesafedir. Victor Borges }\end{array}$ \\
\hline Medeniyetimize Yön verenler (S. 156) & Nazım Hikmet Ran tanıtılmıştır. Salkımsöğüt şiiri verilmiştir. \\
\hline
\end{tabular}

Tablo 9: İYİT ders kitabı 9. ünitede geçen kültürel unsurlar. 
9. ünitede önemli turizm merkezlerinden Ş.Urfa'daki Balıklı Gölün resmine yer verilmiştir. Stand up yapan bir komedyen resmi vardır. Asıl konu mizah olduğundan kültürümüzün en önemli mizah ustalarından olan Nasreddin Hoca'dan ve Hasan Kaçan'dan bahsedilmiştir. Ayrıca dünya çocuklarının oynadıkları oyunlara örnekler verilmiştir. Türkiye’de "yă̆ satarım bal satarım” oyunu, Japonya'da "büyük fener” ve İngiltere'de "Ladderjump” oyunlarına örnekler verilmiştir. Gülmekle ilgili olarak iki yabancı yazarın vecizelerine yer verilmiştir. Medeniyetimize yön verenler bölümünde ise şair Nazım Hikmet Ran tanıtılmıştır.

\begin{tabular}{|c|c|}
\hline Ünite sıra no ve sayfa no & Ünitenin adı \\
\hline Ünite 10 (S. 159) & Yastık Altı. \\
\hline Giriş Sayfası Resmi (S. 159) & $\begin{array}{l}\text { Küçük resimlerde kâğıt ve madeni paralar, ekonomi ile ilgili bir } \\
\text { grafik, kredi kartı ve madeni paraları üst üste dizen bir adamın } \\
\text { resmi verilmiştir. }\end{array}$ \\
\hline Üniteye Hazırlık Sorusu (S. 160) & $\begin{array}{l}\text { Walter Scott’un “Paranın öldürdüğü ruh, kılıcın öldürdüğü } \\
\text { bedenden fazladır” sözünün açılanması istenilmektedir. Para } \\
\text { sembolleri verilmiş ve hangi ülkeye ait olduğunun eşleştirilmesi } \\
\text { istenilmektedir. Türk Lirasının üzerindeki resimler verilmiş } \\
\text { kime ait oldukları da verilmiş ve öğrencilere “sizin ülkenizde } \\
\text { kullandığınız parada kimin veya neyin resmi” var? diye } \\
\text { sorulmuştur. }\end{array}$ \\
\hline Okuma A (S. 161) & Dünden bugüne paranın hikâyesi anlatılmıştır. \\
\hline Hazırlık çalışması B (S. 165) & $\begin{array}{l}\text { Hazırlık çalışmasında ekonomi ile ilgili bazı atasözü ve deyimler } \\
\text { verilmiş ve anlamlarıyla eşleştirilmesi istenmiştir. } \\
\text { İnsan, malına gelen zarardan, canına gelmişçesine acı duyar. } \\
\text { (Atasözü) } \\
\text { Gerçekliğinden şüphe edilmeyecek kadar açık. (Deyim) } \\
\text { Değerini düşürecek biçimde bir kimseden yararlanmaya } \\
\text { kalkışmak. (Deyim) } \\
\text { Destekçisi, dayanağı olmayan kimsenin işleri yavaş yavaş yürür. } \\
\text { (Atasözü) } \\
\text { Herhangi bir engel yüzünden elindeki imkândan } \\
\text { yararlanamamak. (Deyim) } \\
\text { Bir şeyin değerini belirtmek, bir şeye değer koymak. (Deyim) }\end{array}$ \\
\hline Okuma B (S. 166) & Türkiye'de enflasyonun tarihsel gelişim anlatılmıştır. \\
\hline Ya siz? (S. 167) & $\begin{array}{l}\text { "Gündelik hayatınızda enflasyonun yeri var mı? Ekonomik } \\
\text { hayatınızı etkileyen unsurlar nelerdir?” Anlatmaları } \\
\text { istenmektedir. }\end{array}$ \\
\hline Dinleme A (S. 168) & $\begin{array}{l}1933 \text { yılında Cemal Reşit Rey tarafindan bestelenmiş bir operet } \\
\text { olan "Lüküs Hayat" anlatılmıştır. }\end{array}$ \\
\hline Yazma (S. 168) & $\begin{array}{l}\text { Metin Eloğlunun "Eloğlu” şiiri verilmiş ve ekonomik hayata } \\
\text { hangi pencereden baktığı sorulmaktadır. }\end{array}$ \\
\hline Hazırlık çalışması C (S. 169) & $\begin{array}{l}\text { Verilen atasözlerinden ne anladıklarını anlatmaları istenmiştir. } \\
\text { Sakla samanı, gelir zamanı. } \\
\text { Her çok azdan olur. } \\
\text { Damlaya damlaya göl olur. } \\
\text { İşten artmaz, dişten artar. } \\
\text { Ak akçe kara gün içindir. } \\
\text { Bol bol yiyen, bel bel bakar. } \\
\text { Ayağını yorganına göre uzat. }\end{array}$ \\
\hline
\end{tabular}




\begin{tabular}{|c|c|}
\hline Dinleme B (S. 172) & Enerji etiketi ile ilgili bir metin verilmiştir. \\
\hline Konuşma (S. 172) & $\begin{array}{l}\text { Ülkenizde ferdi, ailevi ve toplumsal olarak ne gibi tasarruf } \\
\text { tedbirleri uygulanmaktadır? Sizin bu konudaki önerileriniz } \\
\text { nelerdir? Konuşmaları istenmektedir. }\end{array}$ \\
\hline Kültürrden kültüre (S. 173) & $\begin{array}{l}\text { Dünya ekonomik krizlerine örnekler verilmiştir. } 1994 \text { Meksika } \\
\text { Ekonomik Krizi, } 1994 \text { Türkiye Krizi, } 1997 \text { Endonezya Ekonomik } \\
\text { Krizi. }\end{array}$ \\
\hline Sözün özü (S. 174) & $\begin{array}{l}\text { Ekonomi ile ilgili veciz sözler verilmiş ve açıklanmaları } \\
\text { istenmiştir. } \\
\text { Eğer paranın değerini bilmek istiyorsan, git bir kimseden borç } \\
\text { para iste. Benjamin Franklin } \\
\text { Eldeki para hürriyetin adaletidir. Fakat peşi kovalanan para, } \\
\text { tam tersine kölelik aletidir. J.J. Rousseau } \\
\text { Kılavuzu para olana her kapı açıktır. Skaspeare } \\
\text { Para bir hiçliği bile birinci yere getiren biricik yoldur. } \\
\text { Dostoyevski } \\
\text { Para her şeyi yapar diyen adam, para için her şeyi göze alan } \\
\text { adamdır. Benjamin Franklin } \\
\text { Paranın saklanması, kazanılmasından daha zahmetli bir iştir. } \\
\text { Montaigne }\end{array}$ \\
\hline Medeniyetimize Yön verenler (S. 174) & $\begin{array}{l}\text { Filistinli yazar Mahmut Derviş anlatılmıştır. "Filistinli Sevgili" } \\
\text { adlı şiiri verilmiştir. }\end{array}$ \\
\hline
\end{tabular}

Tablo 10: IYİT ders kitabı 10. ünitede geçen kültürel unsurlar

10. ünitenin konu başlığı ekonomi, finanstır ve parayla ilgili görsellere yer verilmiştir. Kâğıt para, madeni para, kredi kartı resimlerine yer verilmiştir. Paralar üzerindeki resimlerin kimlere ait oldukları sorulmuştur. Ekonomi ile ilgili bazı atasözü ve deyimlere örnekler verilmiştir. Ayrıca Türkiye'de yaşanılan enflasyonun tarihinden bahsedilmiştir. Enerji konusundan ve tasarruf tedbirlerinden bahsedilmiştir. Dünyada yaşanılan büyük ekonomik krizlerden bahsedilmiştir. 1994 Türkiye Krizi, 1994 Meksika Ekonomik Krizi, 1997 Endonezya Ekonomik Krizi. Parayla ilgili yabancı ünlülerden vecizelere yer verilmiştir. Son olarak Filistinli yazar Mahmut Derviş anlatılmıştır. Aslında bu ünitedeki konular evrensel konulardır. Çünkü ekonomi, finans, enflasyon, kriz, para gibi olgular ve olaylar hemen hemen her ülkede karşılaşılabilecek konulardır.

\begin{tabular}{|l|l|}
\hline Ünite sıra no ve sayfa no & Ünitenin adı \\
\hline Ünite 11 (S. 177) & Dünya. \\
\hline Giriş Sayfası Resmi (S. 177) & $\begin{array}{l}\text { Antik Efes tiyatrosu vardır. Altta küçük resimler Dünyamızla } \\
\text { ilgilidir. Yerkürenin resmi, sahilde akşam vakti oturan bir } \\
\text { adam, gün batımı ve bir heykel resmi mevcuttur. }\end{array}$ \\
\hline Ya siz? A (S. 179) & $\begin{array}{l}\text { “Sizin kültürünüzde Dünyamızla ilgili eski zamanlara ait } \\
\text { inanışlar nelerdir?” diye sorulmaktadır. }\end{array}$ \\
\hline Yazma (S. 180) & $\begin{array}{l}\text { Bir ağaç, herhangi bir prensten daha soyludur. Alexander } \\
\text { Pope’un sözünden yola çıarak doğayla ilgili düşüncelerini } \\
\text { anlatmaları istenmektedir. }\end{array}$ \\
\hline Ya siz? B (S. 182) & $\begin{array}{l}\text { "Ülkenizde çevre sorunları ne kadar ciddiye alınıor? Bu } \\
\text { konularda ne gibi çalışmalar yapıllyor?” Bilgi vermeleri } \\
\text { istenmektedir. }\end{array}$ \\
\hline Sözün özü (S. 188) & $\begin{array}{l}\text { Verilen özlü sözleri öğrencilerin kendi ifadeleriyle açlklamaları } \\
\text { istenmektedir. }\end{array}$ \\
\hline
\end{tabular}




\begin{tabular}{|c|c|}
\hline & $\begin{array}{l}\text { Uygarlık, insanlarla doğanın arasını açmıştır. Hüseyin Rahmi } \\
\text { Gürpınar } \\
\text { Çiçeklerin olmadığı yerde insanlar yaşayamaz. Napolyon } \\
\text { Bırakın da tabiat size dadılık etsin. Wordworth. } \\
\text { Yaş kesen baş keser. Atasözü } \\
\text { Dünya herkesin ihtiyacına yetecek kadarını sağlar, herkes } \\
\text { hırsına yetecek kadarını değil. Mahatma Gandhi } \\
\text { Ancak en son ağaç kesildikten, en son nehir zehirlendikten ve } \\
\text { en son balık tutulduktan sonra anlayacaksınız ki, insan parayı } \\
\text { yiyemez. Kızılderili Cree } \\
\text { Doğa, bize dedelerimizden kalan bir miras değil, torunlarımıza } \\
\text { bırakacağımız bir emanettir. Kızılderili Duwanish } \\
\text { Öylesine ciddiye alacaksın ki yaşamayı, yetmişinde bile zeytin } \\
\text { dikeceksin. Nazım Hikmet }\end{array}$ \\
\hline Kültürden Kültüre (S. 187) & Dünya Çevre Günü tanıtılmıştır. \\
\hline Medeniyetimize Yön verenler (S. 188) & Ahmet Hamdi Tanpınar anlatılmaktadır. \\
\hline
\end{tabular}

Tablo 11: IYİT ders kitabı 11. ünitede geçen kültürel unsurlar.

11. ünitenin konusu dünya ve çevre sorunlarıdır ve resimlerde Antik Efes tiyatrosunun resmi ve yer kürenin resmi verilmiştir. Dünyanın oluşumuyla ilgili inanışlardan ve doğanın korunmasıyla ilgili ne yapılabilir sorusundan bahsedilmektedir. Günümüzün en önemli sorunlarından biri olan küresel ısınmadan bahsedilmektedir. Ayrıca Dünya Çevre Gününden bahsedilmektedir. Doğayla ilgili olarak Türk ve yabancı ünlülerin vecizelerine yer verilerek bunların açlklanması istenmiştir. Medeniyetimize yön verenler bölümünde Ahmet Hamdi Tanpınar tanıtılmıştır.

\begin{tabular}{|l|l|}
\hline Ünite sıra no ve sayfa no & Ünitenin adı \\
\hline Ünite 12 (S. 191) & Dördüncü Kuvvet Medya. \\
\hline Giriş Sayfası Resmi (S. 191) & $\begin{array}{l}\text { Süleymaniye camisinin resmi vardır. Alttaki küçük resimler ise } \\
\text { gazete okuyan baba-oğul, Kız Kulesi, bilgisayar ve internete } \\
\text { ayağından zincirle bağlı bir kişi verilmiştir. }\end{array}$ \\
\hline Külttürden kültüre (S. 211) & $\begin{array}{l}\text { Tv dizilerinin meşhur ettiği şehirlerden bahsedilmektedir. } \\
\text { 1.”Sizin ülkenizde yayınlanan dizilerin ülke ekonomisine bir } \\
\text { katkısı var m?? } \\
\text { 2.’Ülkenizin dünya tarafindan tanınan bir dizisi var mı?” diye } \\
\text { sorulmaktadır. }\end{array}$ \\
\hline Medeniyetimize Yön verenler (S. 122) & Yunus Emre tanıtılmaktadır. \\
\hline
\end{tabular}

Tablo 12: IYYiT ders kitabı 12. ünitede geçen kültürel unsurlar.

12. ünitenin konusu medyadır ve gençlerin medya tüketiminden, sosyal medya araçlarından, bahsedilmektedir. Bazı şehirlerin bazı TV dizileri sayesinde meşhur oldukları belirtilmektedir. Örneğin; Muhteşem Yüzyıl dizisi İstanbul'u Araplara tekrar hatırlattı, ayrıca bu dizinin aralarında Bosna Hersek, Hırvatistan, İran, Arnavutluk ve Afganistan gibi ülkelerin de bulunduğu 41 ülkeye ihraç edildiğinden bahsedilmektedir. Ya da "Hawaii Lost'un" çekildiği Oahu adası şimdi turizm merkezi olduğu belirtilmektedir. Kopenhag/ Danimarka- Malmö/ İsveç/ "Köprü” dizisi. Danimarka - İsveç ortak yapımı olan "The Bridge"/ "Köprü" dizisini izleyenin o köprüye koştuğu söylenmektedir. Sherlock Holmes’in "out Kurt Wallander in Stokholm"/ İsveç/ "Wallander" isimli bir dedektifin başından geçenlerin anlatıldığı dizi ise İsveç’in küçük kasabası olan "Ystad" da geçiyor ve o kasabayı meşhur ettiğinden söz edilmektedir. Ayrıca bu ünitede Süleymaniye camisinin resmi, Kız Kulesinin resmi ve bilgisayar- 
internetle ilgili resimlere de yer verilmiştir. Kısaca Tv dizilerinden bahsedilmiştir. Son olarak Yunus Emre'den bahsedilmektedir.

\section{Almanca em neu (C1) ders kitabında ünite bazında geçen kültürel unsurlar}

Em neu ders kitabında yer alan kültürel unsurlar 4 temel dil becerisi altında sınıflandırılarak aşağıdaki tabloda verilmiştir.

\begin{tabular}{|c|c|}
\hline Ünite sıra no ve sayfa no & Ünitenin adı \\
\hline Ünite 1 (S. 9) & Tüm dünyadan haberler \\
\hline Giriş Sayfası Resmi (S. 9) & Bir kişiye ait fotoğraf ve onunla ilgili kısa bilgiler mevcuttur. \\
\hline Üniteye Hazırlık Sorusu (S. 10) & $\begin{array}{l}\text { Hazırlık çalışması bölümünde haberler konusuyla ilgili bir soru } \\
\text { vardır. “Ne tür medya araçlarını kullanıyorsunuz? Ne sıklıkla } \\
\text { kullanıyorsunuz? Avantaj ve dezavantajları nelerdir?”. } \\
\text { Günlük gazete, radyo, TV ve İnternetten hangilerini kullandıkları } \\
\text { sorulmaktadır. }\end{array}$ \\
\hline Okuma Metni A (S. 10) & $\begin{array}{l}\text { Dünyanın değişik ülkelerinden farklı haber ajanslarının geçtiği } \\
\text { haberlere yer verilmiştir. Hamburg, Ottawa, Londra, Barcelona, } \\
\text { Viyana ve Yeni Delhi'den haberler. Haber ajansları olarak AP, DPA, } \\
\text { AFP örnek olarak verilmiştir. }\end{array}$ \\
\hline Kelime dağarcı̆̆ı (S. 12) & Söylemek fiili ile ilgili eş anlamlı fiiller verilmiştir. \\
\hline Yazma (S. 13) & $\begin{array}{l}\text { İki fotoğraf verilmiştir ve bu fotoğrafları ilginç yapan kısa bir gazete } \\
\text { haberi yazmaları istenmektedir. }\end{array}$ \\
\hline Okuma 2 (S. 14-15) & $\begin{array}{l}\text { Nesli tükenmekte olan boz ayllarla ilgili dört tane kısa haber } \\
\text { verilmiştir. Bunlarla ilgili sorular sorulmuştur. }\end{array}$ \\
\hline Konuşma (S. 16) & $\begin{array}{l}\text { Konuşma bölümünde günlük bir gazeteden ilginç bir haber bulup } \\
\text { bunu snnfta anlatmaları istenmektedir. Burada ünlü Alman } \\
\text { gazetelerinin resimleri de verilmiştir. Die Zeit, die Welt, Frankfurter } \\
\text { Allgemeiner, Süddeutsche Zeitung. }\end{array}$ \\
\hline Dinleme (S. 17) & $\begin{array}{l}\text { TV'de ne tür yayınları izledikleri sorulmaktadır. Daha sonra bir } \\
\text { akşama ait günlük yayın akışnı dinlemeleri isteniyor ve sorulan } \\
\text { sorulara cevap vermeleri istenmektedir. Bu bölümde bir küçük resim } \\
\text { mevcuttur. Bir film karesi verilmisstir. Bazı dizi adları verilmisstir. } \\
\text { "Das Leben der anderen”, Der Blick des Odysseus", Die weisse } \\
\text { Massai” ve “Der Totmacher". }\end{array}$ \\
\hline
\end{tabular}

Tablo 13: em neu ders kitabı 1. ünitede geçen kültürel unsurlar

1.ünitenin konusu medyadır ve ilgili bir resme yer verilmiştir. Daha sonra ünlü Alman gazetelerinin (Die Zeit, Die Welt, Frankfurter Allgemeine, Süddeutsche Zeitung) sayfalarından örnekler verilmiştir. Daha sonra haber yazılması için iki farklı fotoğraf verilmiştir. Boz ayılarla ilgili resim ve haberler verilmiştir. Bu bölümde ağırlıklı olarak Alman kültürüne ait unsurlara yer verilmiştir.

\begin{tabular}{|l|l|}
\hline Ünite sıra no ve sayfa no & Ünitenin adı \\
\hline Ünite 2 (S. 19) & Finans. \\
\hline Giriş Sayfası Resmi (S. 19) & $\begin{array}{l}\text { Bir kişinin fotoğrafı verilmiştir. Bu kişi ceplerini göstererek hiç } \\
\text { parası olmadığını anlatmaya çalışmaktadır. }\end{array}$ \\
\hline Üniteye Hazırlık Sorusu (S. 19) & $\begin{array}{l}\text { Hazırlık çalışması bölümünde resimdeki kişi hangi durumda } \\
\text { bulunuyor? Kime başvurabilir? Soruları yöneltilmektedir. }\end{array}$ \\
\hline Kelime dağarcığı (S. 2o) & $\begin{array}{l}\text { Geçim masrafları konusu ele alınmaktadır. Aylık harcamalar. Neye } \\
\text { ne kadar harcanmaktadır? Ortalama bir maşla bir Almanın aylık }\end{array}$ \\
\hline
\end{tabular}




\begin{tabular}{|c|c|}
\hline & $\begin{array}{l}\text { harcamalarını gösteren grafiği öğrencilerin yorumlamaları } \\
\text { istenmekte ve daha sonra kendi ülkenizdeki maaşla karşılaştırın } \\
\text { denilmektedir. Harcamalar örtüşmekte midir? }\end{array}$ \\
\hline Yazma 1 (S. 21) & $\begin{array}{l}\text { Geçim masrafları: Uluslararası. Ülkenizdeki harcamalarla ve } \\
\text { Almanya'daki harcamaların ne olduğunu araştırın ve daha sonra bir } \\
\text { gazetede yayınlanacak şekilde bilgilendirici bir metin yazın } \\
\text { denilmektedir. }\end{array}$ \\
\hline Dinleme 1 (S. 22) & $\begin{array}{l}\text { "Bankada ne yapılır? Verilen kişilerin planları ve ihtiyaçlarının ne } \\
\text { olduğunu dinleyin ve bankada hangi birimin hangi işlerle uğraştığını } \\
\text { bulunuz" denilmektedir. Bu bölümde çek, kredi kartı resimleri } \\
\text { mevcuttur. }\end{array}$ \\
\hline Okuma Metni 1 (S. 23-24) & $\begin{array}{l}\text { Alışveriş yapmak ve internet üzerinden online ödeme konusu ele } \\
\text { alımmaktadır. Online alışverişle ilgili iki biliminsanının yazdığı bir } \\
\text { kitap tanıtılmaktadır. İnternette yapılan alışverişin avantaj ve } \\
\text { dezavantajlarından bahsedilmektedir. }\end{array}$ \\
\hline Dinleme 2 (S. 25) & $\begin{array}{l}\text { Bir broşür resmi verilmiştir ve üzerinde ”Webshop Verkaufe Artikel } \\
\text { über ebay für SIE!" Webshopta çalışan kişiyle yapılan bir danışma } \\
\text { telefon görüşmesini dinleyin denilmektedir. }\end{array}$ \\
\hline Okuma 2 (S. 26-27) & $\begin{array}{l}\text { Metinde Avrupa'da 1980'li yıllarda başlayan; birlikte seyahat ederek } \\
\text { yol masrafinı bölüşme ve yine geçici bir süre birine evini kiralama, } \\
\text { günlük, haftalı gibi konularla ilgili (bla-bla) metinler verilmiştir. } \\
\text { Ortak seyahat ve ortak oturma konusuyla ilgili bir makaleye yer } \\
\text { verilmektedir. (Bla-bla). Konu başlığı: Çok uzaktasınız ama } \\
\text { evdesiniz. }\end{array}$ \\
\hline Yazma 2 (S. 28) & $\begin{array}{l}\text { Bir remi bir de resmi olmayan mektup yazmaları istenmektedir. } \\
\text { Ortak seyahat ve ortak barınma konusuyla ilgili olarak mektup } \\
\text { yazmaları istenmektedir. }\end{array}$ \\
\hline Konuşma (S. 29) & $\begin{array}{l}\text { Ö ğrenci evleri hakkında konuşmaları istenmektedir. Bir de çizim } \\
\text { verilmiştir. }\end{array}$ \\
\hline
\end{tabular}

Tablo 14: em neu ders kitabı 2. ünitede geçen kültürel unsurlar

2.ünitenin konusu finanstır ve züğürt bir kişinin fotoğrafı verilmiştir. Geçim masrafları ile ilgili bir grafik verilmiş ve Almanya'da yaşayan bir vatandaş ile kendi ülkesinde yaşayan vatandaşın gelir gider tablosunu karşılaştırmaları istenmiştir. Harcama kültürlerinin karşılaştırılması. Finansla ilgili olarak kredi kartı ve çek resimleri mevcuttur. Online alışverişten bahsedilmektedir. Bir başka konu ise birlikte seyahat etme ve birlikte kalma. Son yıllarda tercih edilen bir seyahat türüdür. "BlablaCar", aracında boş koltuklarıyla yolculuk yapan sürücülerle, aynı yöne gitmek isteyen yolcuları buluşturan, yolculuk paylaşım ağıdır (blablacar.com.tr). Yani masrafları bölüşme konusuyla ilgili iki metin verilmiştir.

\begin{tabular}{|l|l|}
\hline Ünite sıra no ve sayfa no & Ünitenin adı \\
\hline Ünite 3 (S. 31) & Edebiyat \\
\hline Giriş Sayfası Resmi (S. 31) & $\begin{array}{l}\text { İki öğrencinin resmi vardır. Biri kitap okurken diğeri Tv } \\
\text { izlemektedir. }\end{array}$ \\
\hline Üniteye Hazırlık Sorusu (S. 31) & $\begin{array}{l}\text { Hazırlık çalışması bölümünde bu resimleri yorumlamaları ve ne tür } \\
\text { kitaplar okudukları sorulmaktadır. }\end{array}$ \\
\hline Konuşma (S. 32) & $\begin{array}{l}\text { Sesli kitap hakkında konuşmaları istenmektedir. Dinledikleri sesli } \\
\text { bir kitabı sınıfta tanıtmaları istenmektedir. }\end{array}$ \\
\hline Okuma (S. 33) & $\begin{array}{l}\text { Yaşlı insanların hayatları konulu Bertolt Brecht’in “Die unwürdige } \\
\text { Gresin” adlı hikâyesi ele alınmaktadır. Ve bu hikâye ile ilgili sorular } \\
\text { sorulmaktadır. }\end{array}$ \\
\hline
\end{tabular}




\begin{tabular}{|l|l|}
\hline Yazma (S. 38) & $\begin{array}{l}\text { Yaşlı insanlar nerede yaşamalı? Aileleriyle birlikte mi huzur evinde } \\
\text { mi? Bu konuyla ilgili bir rapor hazırlamaları istenmektedir. }\end{array}$ \\
\hline Kelime dağarcı̆̆ı (S. 39) & $\begin{array}{l}\text { Kişisel özellikler ve ön yargılar ile ilgili kelimeler ele alınmaktadır. } \\
\text { Ayrıca kalıplaşmış ifadeler, basmakalıp ifadeler ile ilgili sorular } \\
\text { sorulmaktadır. }\end{array}$ \\
\hline Konuşma 2 (S. 40) & $\begin{array}{l}\text { Önyargılara karşı hazırlanmış iki posterden birini seçmeleri ve neden } \\
\text { seçtiklerini anlatmaları istenmektedir. }\end{array}$ \\
\hline Dinleme (S.41) & $\begin{array}{l}\text { Mackie Messer’in “Moritat” adlı şarkısını dinlemeleri ve sorulara } \\
\text { cevap vermeleri istenmektedir. Daha sonra şarkıda boş bırakılan } \\
\text { yerleri tamamlamaları istenmektedir. }\end{array}$ \\
\hline
\end{tabular}

Tablo 15: em neu ders kitabı 3. ünitede geçen kültürel unsurlar

3.ünitenin konusu edebiyattır ve kitap okuyan ve Tv izleyen iki kişinin resmi verilmiştir. Bertolt Brecht’in bir hikâyesi ele alınmıştır. Yaşlı insanların kimin yanında kalmaları gerektiği sorulmaktadır. Önyargılarla ilgili kelimeler verilmiştir. Bunlar: unaufrichtig (samimiyetsiz, ikiyüzlü), traditionsverbunden (geleneklerine bağll), eitel (kendini beğenmiş), eingebildet (kibirli), unnahbar (çekingen, içine kapanık), draufgängerisch (atılgan, gözü pek), frech (yaramaz, utanmaz), beleibt (şişman). Ayrıca basmakalıp ifadelerle ilgili bazı cümleler verildi. Örneğin; Almanlar genellikle uyumludur, Ruslar melankolik olarak kabul edilir, birçok bilim insanı sıkıcı insanlardır gibi. Bunlar hakkında ne düşündükleri sorulmaktadır. Dinleme bölümünde Mackie Messer'e ait bir şarkı verilmiştir.

\begin{tabular}{|c|c|}
\hline Ünite sıra no ve sayfa no & Ünitenin adı \\
\hline Ünite 4 (S. 43) & İyi hal. \\
\hline Giriş Sayfası Resmi (S. 43) & $\begin{array}{l}\text { Üç tane resim verilmiştir. Biri alışverişte kasada, diğeri restoranda } \\
\text { yemek yerken cep telefonuyla konuşan biri, üçüncü resimde bir } \\
\text { ofisten çkan kişinin resmi verilmiştir. }\end{array}$ \\
\hline Üniteye Hazırlık Sorusu (S. 43) & $\begin{array}{l}\text { Hazırlık çalışması bölümünde hangi davranış türleri tasvir edildiği } \\
\text { sorulmaktadır. }\end{array}$ \\
\hline Dinleme (S. 44) & $\begin{array}{l}\text { Bir resim verilmiştir. Üç kişi arasında geçen konuşmayı dinlemeleri } \\
\text { ve sorulan sorulara cevap vermeleri istenmektedir. Burada görgü } \\
\text { kurallarından bahsedilmektedir. }\end{array}$ \\
\hline Okuma (S. 45-46) & $\begin{array}{l}\text { Görgü kuralları ile ilgili bir liste verilmiştir. Ve hangi duruma ait } \\
\text { oldukları sorulmaktadır. İletişim, masa adabı, selamlama/vedalaşma } \\
\text { ve davet hakkındadır. Hangi kuralın hangi konu başlığına ait } \\
\text { olduğunu bulmaları istenmektedir. Sınıflandırma yapmaları } \\
\text { istenmektedir. }\end{array}$ \\
\hline Yazma (S. 47) & $\begin{array}{l}\text { Farklı ülkeler farklı adetler. Verilen adetlerden üç dört tane seçip ne } \\
\text { tür davranışların kırıcı, incitici olacağını yazmaları istenmektedir. }\end{array}$ \\
\hline Yazma 2 (S. 48) & $\begin{array}{l}\text { Bir teşekkür mektubu yazmaları istenmektedir. Resmi mektup } \\
\text { olarak. "Bir iş görüşmesine katıldınız diğer adaylarla ve orada içinde } \\
\text { önemli belgelerin olduğu çantanızı unuttunuz. Bu çantayı iş yeri } \\
\text { müdüründen nasıl talep edersiniz?" diye sorulmaktadır. }\end{array}$ \\
\hline Konuşma (S. 49) & $\begin{array}{l}\text { Almanca konuşulan ülkelere ait selamlama biçimleriyle ilgili } \\
\text { resimler verilmiştir. Hangilerinin resmi, hangilerinin resmi olmayan } \\
\text { olduğu sorulmaktadır. Ülkenizde durum nasıldır? Anlatınız } \\
\text { denilmektedir. }\end{array}$ \\
\hline Okuma 2 (S. 50-52) & $\begin{array}{l}\text { Almanya hakkında ne biliyorsunuz adlı bir metin verilmiştir. Alman } \\
\text { ekmeği, Alman müziği, Alman dakikliği, Almanya'da hizmet } \\
\text { sunumu, Alman araç sürücüleri ve Alman nezaketi hakkında bilgiler } \\
\text { verilmiştir. }\end{array}$ \\
\hline
\end{tabular}




\begin{tabular}{|l|l|}
\hline Kelime dağarcı̆̆ı (S. 53) & Sözlü iletişim konusu. Bazı filler verildi eş anlamlılarını bulmaları \\
& istenmektedir. Ayrıca birkaç deyim ile atasözü resimlerle birlikte \\
& verilmiş ne anlama geldikleri sorulmuştur. Bu deyim ve atasözleri \\
& şunlardır: Reden, wie einem der Schnabel gewachsen ist (dobra \\
& dobra konuşmak,). Reden ist Silber, Schweigen ist Gold.(Söz \\
& gümüşse, sükut altındır). Wie ein Wasserfall reden (Çenesi \\
& durmamak, çok hılı ve aralıksız konuşmak). Nicht auf den Mund \\
& gefallen sein.(Hazırcevap olmak). Um den heissen Brei herumreden. \\
& (Lafi ağzında gevelemek, sadede gelmemek). Einem das Wort im \\
& Mund umdrehen. (Lafi çarpıtmak, tersine çevirmek). Kein Blatt vor \\
& den Mund nehmen (Ağzinda bakla islanmamak).
\end{tabular}

Tablo 16: em neu ders kitabı 4. ünitede geçen kültürel unsurlar

4.ünitenin konusu iyi haldir ve üç farklı mekânda üç farklı resim verilmiştir. Görgü kurallarıyla ilgili bir dinleme metni verilmiştir. Daha sonra farklı ülkelere ait farklı görgü kurallarından bahsedilmiştir. Kendi ülkesindeki bu görgü kurallarını karşılaştırmaları istenmektedir. Kültürlerarası kıyaslama. Daha sonra Almanya ve Almanlar hakkında İngiliz diplomatın düşüncelerine yer verilmiştir. Alman kültürü tanıtılmaktadır. Son olarak bazı deyim ve atasözleri resimlerle verilmiştir ve bunların açıklanması istenmektedir. Bu ünitede kültürlerarası unsurlara daha fazla yer verilmiştir.

\begin{tabular}{|c|c|}
\hline Ünite sıra no ve sayfa no & Ünitenin adı \\
\hline Ünite 5 (S. 55) & Psikoloji \\
\hline Giriş Sayfası Resmi (S. 55) & $\begin{array}{l}\text { İki tane resim verilmiştir. Biri tenis oyuncusu, maçı kazanmış sevinç } \\
\text { gösterisinde bulunuyor, diğeri maçı kaybetmiş, başı öne eğik bir } \\
\text { vaziyette yürümektedir. }\end{array}$ \\
\hline Üniteye Hazırlık Sorusu (S. 55) & $\begin{array}{l}\text { Hazırlık çalışması bölümünde resimde görülen sporcuların } \\
\text { durumlarnın tasvir edilmesi istenmektedir. Vücut dilinden ne } \\
\text { anlıyorsunuz sorusu yöneltilmiştir. }\end{array}$ \\
\hline Okuma (S. 56-57) & $\begin{array}{l}\text { Okuma metninin üstünde belini tutan bir kadın resmi vardır. Metnin } \\
\text { konusu beli bükülmek. }\end{array}$ \\
\hline Okuma 2 (S. 58) & $\begin{array}{l}\text { Sigmund Freud hakkında bir metin verilmiştir. Biyografisi hakkında } \\
\text { sorular sorulmuştur. }\end{array}$ \\
\hline Dinleme (S. 59-60) & $\begin{array}{l}\text { Psikoanalistler ne yapar? Bununla ilgili radyo programı vardır. Bu } \\
\text { röportajı dinlemeleri istenmektedir. }\end{array}$ \\
\hline Kelime Bilgisi (S. 61) & $\begin{array}{l}\text { Ruh ve bedenle ilgili kelimeler verilmiştir. Örneğin; der Geist, die } \\
\text { Seele, das Herz, der Verstand. Bunların ana dilinizdeki karşıllkları } \\
\text { nelerdir? Yazmaları istenmektedir. İki tane deyim verilmiş çizimlerle } \\
\text { birlikte bunların ne anlama geldiğini bulmaları istenmiştir. } \\
\text { Deyimler: "Ein Herz und eine Seele sein", "Sich die Seele aus dem } \\
\text { Leib schreien". Ayrıca } 7 \text { deyim ve anlamları verilmiş ve bunların } \\
\text { eşleştirilmeleri istenmiştir. Bu deyimler: eine schwarze Seele haben } \\
\text { (kötü huylu olmak), ein Herz und eine Seele sein (ayrılmaz ikili } \\
\text { olmak), eine Seele von einem Menschen sein (iyi kalpli bir insan), } \\
\text { jemandem aus der Seele sprechen (birinin hislerine tercüman } \\
\text { olmak), jemandem die Seele aus dem Leib fragen (birisini soru } \\
\text { yağmuruna tutmak, aklına geleni sormak), sich die Seele aus dem } \\
\text { Leib schreien (avaz avaz bağırmak), sich etwas von der Seele reden } \\
\text { (içini dökmek). }\end{array}$ \\
\hline Okuma 3 (S. 62) & Yaratıcı insanlar konusu ele alınmıştır. \\
\hline Konuşma (S. 64) & $\begin{array}{l}\text { Dört tane resim verilmiş ve bunlar hakkında konuşmaları } \\
\text { istenmiştir. Dört resim dört tip insan. Bu tipler: der Pedant (titiz), } \\
\text { die Kulturtante (sanat sever), der Hochstapler (ihmalkar) ve der } \\
\text { Messie (maymun iştahlı). }\end{array}$ \\
\hline
\end{tabular}


Yazma (S. 65)

Masa başında çalışan bir kadın resmi verilmiştir. Daha sonra resmi olmayan bir mektup örneği verilmiştir. Zamanı nasıl verimli kullanacağı ile ilgili bir arkadaşından öneri istemektedir.

Tablo 17: em neu ders kitabı 5. ünitede geçen kültürel unsurlar

5.ünitenin konusu psikolojidir ve iki sporcunun fotoğrafı paylaşılmıştır. Biri galip, diğeri mağlup olarak yürümektedir. Psikolojilerini yansıtan resimler. Daha sonra bel ağrısı çeken bir kadının resmi verilmiştir. Bazen ağrıların fizyolojik değil psikolojik olduğu anlatılmaya çalışılmıştır. Daha sonra Sigmund Freud tanıtılmıştır. İki deyim tasvir edilmiş ve onların kendi ana dilindeki karşıllğı nedir diye sorulmuştur. Ayrıca 7 deyim ve anlamları verilmiş, bunların eşleştirilmeleri istenmiştir. Bu ünitede deyimlere epeyce yer verilmiştir. Daha sonra dört farklı insanı anlatan dört durumdan bahsedilmektedir. Bu kişilerin ruh hallerinin tasviri istenmiştir. Zamanı verimli kullanmakla ilgili tüyolar verilmiştir. Bu ünitede kültürel öge olarak Sigmund Freud'a, deyimlere ve mecazlara yer verilmiştir. Diğer konular genel konulardır.

\begin{tabular}{|c|c|}
\hline Ünite sıra no ve sayfa no & Ünitenin adı \\
\hline Ünite 6 (S. 67) & Kariyer \\
\hline Giriş Sayfası Resmi (S. 67) & İyi giyimli iki kadın ve bir erkek resmi vardır. \\
\hline Üniteye Hazırlık Sorusu (S. 67) & $\begin{array}{l}\text { Bu kişileri tasvir etmeleri istenmektedir. Kıyafetleri, görünüşleri. Bu } \\
\text { kişilerle ilgili bir biyografi tasarlamaları istenmektedir. }\end{array}$ \\
\hline Konuşma (S. 68) & $\begin{array}{l}\text { Kariyerle ilgili bir anket verilmiştir. Bu ankete cevap vermeleri } \\
\text { istenmiştir. }\end{array}$ \\
\hline Okuma 1 (S. 69-71) & $\begin{array}{l}\text { Başarılı kadınlarla ilgili Nobel ödüllü biyolog Christina Nüsslein- } \\
\text { Volhard’la yapılmış bir röportaja yer verilmiştir. }\end{array}$ \\
\hline Dinleme (S. 72) & $\begin{array}{l}\text { Personel alımında önemli olan noktalar nedir? sorusuyla ilgili insan } \\
\text { kaynakları müdürünün görüsslerini dinlemeleri istenmektedir. Nelere } \\
\text { dikkat ettiği vurgulanmaktadır. }\end{array}$ \\
\hline Kelime Bilgisi (S. 73-74) & $\begin{array}{l}\text { Maaş ile ilgili kelimelere yer verilmiştir. Bir bordroda ne tür gelir ve } \\
\text { giderler, kesintiler olduğu açılanmıştır. Örneğin Lohnsteuer (gelir } \\
\text { vergisi), Kirchensteuer (kilise vergisi), Solidaritätszuschlag } \\
\text { (dayanışma yardımı), Rentenversicherung (emeklilik keseneği), } \\
\text { Krankenversicherung (hastalık sigortası), Pflegeversicherung (Yaşlı } \\
\text { bakım sigortası), Arbeitslosenversicherung (işsizlik sigortası). Daha } \\
\text { sonra eşit işe eşit ücret konusunda bir grafik verilmiştir. } \\
\text { Kadın/erkek maaşları, memur/işçi maaşları ve Eski Doğu Almanya } \\
\text { ile Federal Almanya'da çalışanların ortalama kazançlarına yer } \\
\text { verilmiştir. }\end{array}$ \\
\hline Okuma 2 (S. 75-76) & $\begin{array}{l}\text { Hurslı insanlar ile ilgili bir metin verilmiştir. Kariyer yaparken hangi } \\
\text { özelliklere sahip olunması konusunda ipuçları verilmiştir. }\end{array}$ \\
\hline Yazma (S. 77) & $\begin{array}{l}\text { İş yerinde stres konulu bir istatiksel grafiğe yer verilmiştir. Stresin } \\
\text { nedenleri ile ilgili oranlar gösterilmiştir. Daha sonra grafiği } \\
\text { yorumlamaları istenmektedir. }\end{array}$ \\
\hline
\end{tabular}

Tablo 18: em neu ders kitabı 6. ünitede geçen kültürel unsurlar

6.ünitenin konusu kariyerdir ve iki kadın ile bir erkek resmi verilmiştir. Bunların tasvir edilmesi istenmektedir. Nobel ödüllü Alman bilim insanı biyologla yapılmış bir röportaja yer verilmiştir. Kariyeri hakkında sorular sorulmuştur. Maaşla ilgili bazı terimlere yer verilmiştir. Kadın ile erkeğin kazançları grafikte gösterilmiş ve ücret eşitsizliği hakkında bazı bilgiler verilmiştir. Ayrıca Eski Doğu Almanya'da yaşayanlar ile Federal Almanya'da yaşayan işçi-memur maaşları karşılaştıılmıştır. Çalışma hayatını yakından ilgilendiren iş yerinde stres konusuyla ilgili yapılmış bir çalışmanın grafiği verilmiştir. 


\begin{tabular}{|c|c|}
\hline Ünite sıra no ve sayfa no & Ünitenin adı \\
\hline Ünite 7 (S. 79) & Kriminoloji \\
\hline Giriş Sayfası Resmi (S. 79) & Çatı üstünde duran bir adamın resmi vardır. \\
\hline Üniteye Hazırlık Sorusu (S. 79) & $\begin{array}{l}\text { Aslında bu resim bir polisiye filmden alınmış bir kesittir. Bu resmi } \\
\text { tasvir etmeleri istenmektedir. Daha sonra ögrencilerden izledikleri } \\
\text { bir polisiye filmini anlatmaları istenmektedir. }\end{array}$ \\
\hline Okuma (S. 8o) & $\begin{array}{l}\text { Üç tane çizim verilmiştir ve bu çizimleri tasvir etmeleri istenmiştir. } \\
\text { Daha sonra hırsızlık olayları ile ilgili bir metin verilmiştir. }\end{array}$ \\
\hline Sözcük Bilgisi (S. 81) & $\begin{array}{l}\text { Hukuk ve cinayetle ilgili sözcüklere yer verilmiştir. Anlamları } \\
\text { açıklanmıştır. }\end{array}$ \\
\hline Okuma 2 (S. 82-83) & Suç işleyen çocuklarla ilgili uzmanların görüşlerine yer verilmiştir. \\
\hline Konuşma (S. 84) & $\begin{array}{l}\text { Okuma metninde yer verilen uzmanların görüşleriyle ilgili } \\
\text { öğrencilerin ne düşündükleri sorulmaktadır. Bu konuyla ilgili bir } \\
\text { münazara yapmaları istenmektedir. }\end{array}$ \\
\hline Yazma (S. 85) & $\begin{array}{l}\text { Verilen resimler eşliğinde bir soygun olayının nasıl gerçekleştiğini } \\
\text { anlatmaları istenmiştir. }\end{array}$ \\
\hline Okuma 3 (S. 86-87) & $\begin{array}{l}\text { Yalan hakkında bir metin verilmiştir. İnsanlar niçin yalan söylerler? } \\
\text { diye sorulmaktadır. }\end{array}$ \\
\hline Dinleme (S. 88-89) & $\begin{array}{l}\text { Yalanla ilgili iki atasözüne yer verilmiştir. "Lügen haben kurze } \\
\text { Beine" (yalancının mumu yatsıa kadar yanar), "Wer dreimal lügt, } \\
\text { dem glaubt man nicht und wenn er auch die Wahrheit spricht" } \\
\text { (yalancının evi yanmış kimse inanmamış). Bunları açıklamaları } \\
\text { istenmektedir. Daha sonra bir radyo programında yalanla ilgili } \\
\text { yapılmış röportajı dinlemeleri istenmiştir. }\end{array}$ \\
\hline
\end{tabular}

Tablo 19: em neu ders kitabı 7. ünitede geçen kültürel unsurlar

7.ünitenin konusu suç ve ceza yani kriminolojidir. Bir film sahnesinden alınmış kişinin resmi verilmiştir. Hırsızlık olayları ile ilgili üç karikatür verilmiştir. Hukuk terimlerine anlamları ile birlikte örnekler verilmiştir. Daha sonra bir soygun olayının nasıl gerçekleştiğiyle ilgili bir resim verilmiştir. Bu ünitede kültürlerarası unsurlara fazla yer verilmemiştir. Daha çok Alman kültürüne ait unsurlara yer verilmiştir. İki atasözüne yer verilmiştir. Bunlar Türkçede de var olan atasözleridir. Aslında konu evrensel ama örnekler yerelden seçilmiştir.

\begin{tabular}{|l|l|}
\hline Ünite sıra no ve sayfa no & Ünitenin adı \\
\hline Ünite 8 (S. 91) & Bilim \\
\hline Giriş Sayfası Resmi (S. 91) & $\begin{array}{l}\text { Giriş sayfasında teknolojiyle ilgili çoğunlukla Alman mucitlerin icat } \\
\text { ettikleri } 7 \text { tane icadın resmi verilmiştir. Bunlar matbaanın icadı, } \\
\text { Mercedes araba, Telefon, Aspirin, MP3, radyoaktif ışın ve röntgen. }\end{array}$ \\
\hline Üniteye Hazırlık Sorusu (S. 91) & $\begin{array}{l}\text { Hazırlık çalışması bölümünde resimde görülen buluşların neler } \\
\text { olduğunu verilen kelimelerle eşleştirmeleri istenmektedir. }\end{array}$ \\
\hline Okuma 1 (S. 92-93) & $\begin{array}{l}\text { Günlük hayatımızı değiştiren yeniliklerle ilgili bir metin verilmiştir. } \\
\text { Bunların ne zaman kimin tarafından icat edildiği ile ilgili kısa } \\
\text { hikâyeleri anlatılmıştır. Bu icatlar banka kartı, kahve filtresi, diş } \\
\text { macunu, termos, hesap makinesi ve otomobildir. }\end{array}$ \\
\hline Yazma (S. 94) & $\begin{array}{l}\text { Altı icadın resimleri verilmiştir. Ampul, bilgisayar klavyesi, monitör, } \\
\text { buzdolabı fotoğraf makinesi ve çamaşır makinesi. Bunlardan birini } \\
\text { seçerek insanların hayatlarını nasıl değiştirdiğini yazmaları } \\
\text { istenmektedir. }\end{array}$ \\
\hline
\end{tabular}




\begin{tabular}{|l|l|}
\hline Kelime Bilgisi (S. 95) & $\begin{array}{l}\text { Bilimle ilgili kelimelere yer verilmiştir. Meslek grupları ve farklı } \\
\text { bilim dallarına örnekler verilmiştir. }\end{array}$ \\
\hline Dinleme (S. 96) & $\begin{array}{l}\text { Bir ilaçlarla ilgili bir kongreyi ile ilgili bir konuşmayı dinlemeleri ve } \\
\text { soruları cevaplamaları istenmektedir. }\end{array}$ \\
\hline Konuşma (S. 97) & $\begin{array}{l}\text { Sunu hazırlamaları istenmiştir. Verilen dört konudan birini seçerek } \\
3-5 \text { dakikalık bir sunum yapmaları istenmiştir. Ayrıca vücut diliyle } \\
\text { ilgili olarak üç adet çizime yer verilmiştir. }\end{array}$ \\
\hline Okuma 2 (S. 98-100) & Aspirin mucidi Felix Hoffmann ile ilgili bir metin verilmiştir. \\
\hline Konuşma 2 (S. 101) & $\begin{array}{l}\text { Bilimdeki yeniliklerden olan gen tekniği, klonlama, tüp bebek ve } \\
\text { organ nakli konusunda bir konuşma yapmaları istenmektedir. }\end{array}$ \\
\hline
\end{tabular}

Tablo 2o: em neu ders kitabı 8. ünitede geçen kültürel unsurlar

8.ünitenin konusu bilimdir ve Alman mucitleri ile icatları resimleriyle birlikte verilmiştir. Hayatımızı değiştiren icatlardan bahsedilmektedir. Bunların hikâyelerinden bahsedilmektedir. Bazı bilim dalları ve mesleklerle ilgili resimlere yer verilmiştir. Aspirinin mucidi Felix Hoffmann’dan bahsedilmiştir. Bilimde yaşanan son teknolojik gelişmelerden bahsedilmiştir. Bu ünitede Alman kültürünü tanıtan değişik mucitlere ve icatlarına yer verilmiştir. Kültürel ögelerin en fazla yer aldığı ünite bu ünitedir.

\begin{tabular}{|l|l|}
\hline Ünite sıra no ve sayfa no & Ünitenin adı \\
\hline Ünite 9 (S. 103) & Sanat \\
\hline Giriş Sayfası Resmi (S. 103) & $\begin{array}{l}\text { Giriş sayfasında ünlü ressam Gustav Klimt’in iki tane tablosuna yer } \\
\text { verilmiştir. }\end{array}$ \\
\hline Üniteye Hazırlık Sorusu (S. 103) & Verilen iki tabloyu tasvir etmeleri istenmektedir. \\
\hline Okuma 1 (S. 104-105) & $\begin{array}{l}\text { Klimt'in Viyana'daki resim atölyesinde yapmış olduğu çalışmalar } \\
\text { anlatılmaktadır. }\end{array}$ \\
\hline Kelime Bilgisi (S. 106) & $\begin{array}{l}\text { Akım ve üslup konusuyla ilgili kelimelere yer verilmiştir. Mimari } \\
\text { akımlar ve sanat akımlarından bahsedilmektedir. Baroktan, Gotik } \\
\text { tarzından, Genç stilden, Klasik akımdan, Post modern akımdan ve } \\
\text { Rönesans'tan. }\end{array}$ \\
\hline Konuşma (S. 107) & $\begin{array}{l}\text { "Yeni bir müzenin yapımında gönüllü olarak çalışıyorsunuz. Ne tür } \\
\text { bir müze yapılmasını isterdiniz?”. Tartışınız denilmektedir. }\end{array}$ \\
\hline Dinleme (S. 108) & $\begin{array}{l}\text { Üç ünlü tablonun (üç kadın: Serena Lederer, Emilie Flöge ve Adele } \\
\text { Bloch-Bauer) tanıtıldı̆ı bir konuşmayı dinleyip soruları } \\
\text { cevaplamaları istenmektedir. Viyanalı üç kadından } \\
\text { bahsedilmektedir. }\end{array}$ \\
\hline Okuma 2 (S. 109-111) & $\begin{array}{l}\text { Şöhrete giden yol adlı bir metin verilmiştir. Burada bir sanat } \\
\text { okuluna girmek için yapılan sinavlar hakkında bilgi verilmiştir. }\end{array}$ \\
\hline Yazma (S. 112) & $\begin{array}{l}\text { Bir Alman arkadaşınızdan mail aldınız ona cevap yazın } \\
\text { denilmektedir. }\end{array}$ \\
\hline Konuşma 2 (S. 113) & $\begin{array}{l}\text { Tiyatro sahnesinden alınmış iki resme yer verilmiştir. Bunları } \\
\text { yorumlamaları istenmektedir. }\end{array}$ \\
\hline
\end{tabular}

Tablo 21: em neu ders kitabı 9. ünitede geçen kültürel unsurlar

9. ünitenin konusu sanattır ve ünlü ressamlardan bahsedilmiştir. Resimleri ve bazı tabloları verilmiş̧ir. Mimari akım ve sanat akımları hakkında bilgiler verilmiştir. Bu bölümde Alman ve Avusturyalı sanatçılar tanıtılmıştır. Kültürel ögelere oldukça fazla yer verilmiştir. 


\begin{tabular}{|l|l|}
\hline Ünite sıra no ve sayfa no & Ünitenin adı \\
\hline Üniteıo (S. 117) & Globalleşme \\
\hline Giriş Sayfası Resmi (S. 117) & $\begin{array}{l}\text { Giriş sayfasında teknolojiyle ilgili üç resim vardır. Resimlerin } \\
\text { ikisindeki kişiler cep telefonuyla konuşurken, diğeri ise laptopun } \\
\text { başında çalışmaktadır. }\end{array}$ \\
\hline Üniteye Hazırlı Sorusu (S. 117) & $\begin{array}{l}\text { Hazırlık çalışması bölümünde resimde görülen buluşların nerede } \\
\text { icat edildikleri sorulmaktadır. “Giydiniz kıyafetler nerede } \\
\text { üretilmiştir?” diye bir soru vardır. }\end{array}$ \\
\hline Dinleme 1 (S. 118) & $\begin{array}{l}\text { Globalleşme ile ilgili bir konuşmayı dinlemeleri ve soruları } \\
\text { cevaplamaları istenmektedir. }\end{array}$ \\
\hline Konuşma (S. 119) & $\begin{array}{l}\text { Globalleşme ile ilgili temel kavramlar verilmiştir. Bunlar: Hizmet } \\
\text { sektörü, sermaye, haberler, mal, eğitim. Globalleşmenin aktörleri, } \\
\text { sonuçları ve koşulları hakkında tartışmaları istenmektedir. }\end{array}$ \\
\hline Okuma 1 (S. 120) & $\begin{array}{l}\text { Üç kişi farklı ülkelerde doğmuş sonra Almanyaya yerleşmiş kendi } \\
\text { hayatları hakkında kısa bilgi vermektedirler. Bunların ortak } \\
\text { noktalarının neler olduğu sorulmaktadır. }\end{array}$ \\
\hline Okuma 2 (S. 121-124) & $\begin{array}{l}\text { İki farklı mimaride ev resmi verilmiştir. Daha sonra memleket } \\
\text { konusu ele alınmıştır. Globalleşen dünyada memleket hasreti } \\
\text { işlenmiştir. Globalleşmeyle birlikte değişen hayat şartları ele } \\
\text { alınmıştır. }\end{array}$ \\
\hline Kelime Bilgisi (S. 125) & Globalleşme ile ortaya çkan yeni sözcüklere örnekler verilmiştir. \\
\hline Yazma (S. 126) & $\begin{array}{l}\text { Globalleşme ile ilgili metinde anahtar sözcükleri bulup yeniden bir } \\
\text { kompozisyon yazmaları istenmektedir. }\end{array}$ \\
\hline $\begin{array}{l}\text { Zamana yolculuk adlı bir konuşmayı dinleyip soruları cevaplamaları } \\
\text { istenmektedir. }\end{array}$ \\
\hline
\end{tabular}

Tablo 22: em neu ders kitabı 10. ünitede geçen kültürel unsurlar.

10. ünitenin konusu küreselleşmedir. Günümüz popüler iletişim araçlarının resimlerine yer verilmiştir. Küreselleşme ile ilgili temel kavramlar açıklanmıştır. İki farklı evin resmi verilmiştir. Memleket, hasret konusu ele alınmıştır. Küreselleşme ile birlikte ortaya çıkan yeni kelimelere örnekler verilmiştir. Bu bölümde kültürlerarası konulara epeyce yer verilmiştir. Ve herkesin aşina olduğu bir konu ele alınmıştır.

\section{Sonuç, tartışma ve öneriler}

IYİT Ders Kitabı incelendiğinde kitapta 63 vecize, 21 Türk atasözü, 11 deyim ve 17 argo kelimenin olduğu görülmektedir. Bu vecizelerin 45 ’ yabancı ünlülere aittir.

Kitapta, Mevlana, Hz. Muhammed gibi dini, Özdemir Asaf, Necip Fazıl Kısakürek gibi edebi ve Fatih Sultan Mehmet gibi tarihi yelpazeden pek çok önemli şahsiyete yer verilmiştir. Her ünitede Medeniyetimize Yön Verenler bölümünde bir edebiyatçı tanıtılmakta ve eserlerinden bir örnek sunulmaktadır. Ayrıca ünitenin içindeki diğer bölümlerde de hazırlık çalışması, okuma, dinleme, konuşma, yazma veya sözün özü bölümünde de edebiyata ve edebiyatçllara yer verilmiştir.

Ya Siz bölümünde öğrenenlere ülkelerinde hangi saat türlerinin kullanıldığı, hangi ünlülerin çocukluk öykülerini bildikleri, aşktan ne anladıkları, büyük ikramiye çıkarsa neler yapacakları, tavlayı mı satrancı sevdikleri, dilekçe yazıp yazmadıkları, yönetmen olsalardı hangi konuda film yapacakları, günümüzde bilge olmanın mümkün olup olmadığı, bilgi teknolojilerini kullanıp kullanamadıkları, ülkelerindeki üniversite sisteminin nasıl olduğu, sanattan ne anladıkları, ülkelerindeki suç oranları ve ceza sistemi hakkında ne bildikleri, mizahın ülkelerindeki popülaritesi, Türkiye'de hangi, mizahçıları tanıdıkları, 
para icat edilmeseydi nasıl alışveriş yapacakları, ekonomik hayatı etkileyen unsurların neler olduğu, Dünyamızla ilgili inanışların neler olduğu, çevre sorunları hakkında neler bildikleri, uzay yolculuğunda bulunmak isteyip istemedikleri, ne tür medya aracı kullandıkları gibi sorular yöneltilerek kendi kültürleriyle Türk kültürünü karşılaştırmaları istenilen toplam 16 soru vardır. Bu sorular incelendiğinde Türk kültüründen ziyade kendi kültürleriyle ilgili sorulara cevap vermeleri beklenmektedir. Kitabın tamamına bakıldığında 94 adet kalıp ifade olduğu görülmektedir.

Em neu Ders Kitabında ise 18 deyim, bir atasözü ve 6 argo söz, 10 adet sizin ülkenizde diye başlayan soru bölümü vardır. 27 edebiyatçı, tiyatrocu, ressam ve bilim insanından bahsedilmektedir. Örneğin; Alfred Brehm, Bertolt Brecht gibi edebiyatçllara, Sigmund Freud, Carl von Linde gibi bilim insanlarına, Heinz Hilgers ve Hans-Dieter Schwind gibi siyasetçilere, Jürgen Dethloff, Gottlieb Daimler, Felix Hoffmann gibi mucitlere, Gustav Klimt, Egon Schiele gibi ressamlara hemen hemen aynı sayıda kişiliğe yer verilmiştir her iki kitapta da.

Görüldüğü üzere IYYIT Ders Kitabında kültürlerarası yaklaşıma göre daha çok konu ve bölüm vardır. Ayrıca kitaplar ünite başlıkları açısından incelendiğinde em neu Ders Kitabı on üniteden, İİT Ders Kitabı 12 üniteden oluşmaktadır. Almanca em neu Ders Kitabında yer alan 8 ünitenin konusu IYYIT Ders Kitabinda da mevcuttur. Bunlar:

$\underline{\text { Em Neu }}$

1.Kisa haberler

2.Finans

3.Edebiyat

4.İyi hal

5.Psikoloji

6.Kariyer Yapma

7.Cinayet

8.Bilim

9.Sanat

10.Globalleşme

\section{IYIT}

12.Dördüncü Kuvvet Medya

10.Yastık Altı

2.Aşk Olsun

3. İşini Şansa Bırakma

5.Film Şeridi Gibi

4.Bir Maruzatım Var

8.Suç ve Ceza

6.Bilgi Dünyası

7.Sanat Sanat İçindir

11.Dünya
9.Hayata Gülümse
1. Öyle Bir Geçer Zaman ki

Almanca em neu Ders Kitabında yer alan Psikoloji (5.ünite) ve Kariyer (6.ünite) konuları İYiT Ders Kitabında yer almamaktadır. IYİT Ders Kitabında yer alan; Öyle Bir Geçer Zaman ki (1.ünite), İşini Şansa Bırakma (3.ünite), Film Şeridi Gibi (5.ünite), Hayata Gülümse (9.ünite) konuları Almanca em neu Ders Kitabında yer almamaktadır. Kısaca ortak olan 8 konu vardır. 
Kültürel unsurlar açısından ünite bazında karşılaştırma yapıldığında ortak olan konular aşağıdaki gibidir: İtalik olarak gösterilenler ortak olan konulardır.

1. ünite kültürden kültüre 12 Hayvanlı Türk Takvimi

2. ünite Evlilik Gelenekleri- Benimmregeln (görgü kuralları)

3. ünite Hurafeler, Dört Yapraklı Yonca, Baykuş, Uğur-Uğursuzluk

4. ünite Türkiye’de Saygı, Kore'de ve Fransa'da Saygı -Benimmregeln (görgü kuralları)

5. ünite Antalya Film Festivali- OSCAR Cannes Film Festivalleri

6. ünite İlk Üniversiteler

7. ünite İstanbul Kültür Sanat Vakfı

8. ünite Eski Türk Kanunları- 12 Levha Hammurabi Kanunları- Kriminalität (cinayet-suç)

9. ünite Dünya Çocukları Nasıl Oynuyor? Türkiye, Japonya ve İngiltere'den örnekler. Benimmregeln (görgü kurallarl)

10. ünite Dünya Ekonomik Krizleri- Finanz (finans)

11. ünite Dünya Çevre Günü- Globalisierung (küreselleşme)

12. ünite TV Dizilerinin Meşhur Ettiği Şehirler. Globalisierung (küreselleşme)

Kültürel unsurlar açısından incelendiğinde; görgü kuralları, cinayet, finans ve küreselleşme konuları ortak konular olarak karşımıza çıkmaktadır. İYİT Ders Kitabının kapağında hem İstanbul'u tanıtan resimlere (Boğaz Köprüsü, Kız Kulesi, Cami) yer verilmiş hem de farklı ülkelerden gelen insanların fotoğraflarına yer verilerek kitabın uluslararası bir işlevinin olduğu ima edilmektedir. Bu işlev kültürlerin buluşması, kaynaşması demektir. Türkçe öğrenmek isteyenler farklı ülkelerden ve farklı milliyetlerden bir araya gelmektedirler. Sadece kitabın kapă̆ında 17 adet farklı resim mevcuttur.

IYİT Ders Kitabının belki olumsuz olarak kabul edilebilecek tarafı dilbilgisi konuları açlklanırken İngilizce olarak da açıllamalar yapılmıştır. Oysa Almanca em neu Ders Kitabında 2. bir dille açıklamalara yer verilmemiştir.

Her ne kadar bu yaklaşım (kültürlerarası) 1980'lerin sonunda ortaya çımışsa da bu yönteme özgü ders teknikleri ve öğrenenlerin başarısını ölçen araştırmalar henüz somut olarak ortaya konulmamıştır. Ayrıca gramerin de yeri ve ağırlığı tam olarak belirtilmemiştir. Bu yüzden iletişimci yaklaşımdan keskin farklılıkları ortaya tam olarak konulamadı (Hahn, 2007: 26). Bu yaklaşımın başarısı ancak kültürler arasında büyük farklılıkların olduğu, yani öğrenilen dil ile o dili öğrenenlerin kültürel farklılıkların çok olduğu gruplarda ortaya çıkar" (Neuner ve Hunfeld, 1993, 122). Yani kültürel farklılıklar ne kadar çoksa bu yöntem o kadar çok iyi sonuç verir. Avrupa ülkeleri arasında bu yöntem çok başarılı olmaz, çünkü kültürleri birbirine çok benzemektedir. Başka bir ifadeyle farklı kültürel ögelerin varlığına odaklanmak, kültürlerarası yaklaşımın temel savıdır. Böylece dilsel ifadeleri belirleyen kültürel unsurlar daha net biçimde ortaya çıkarılmaktadır. Bu nedenle bir Avrupa ülkesini Asya ya da Afrika ile karşılaştırmak daha 
doğru sonuçlara ulaşılmasını sağlar. Zira aradaki kültürel farklılıkların dil kullanımına yansımaları daha belirgin olacaktır. Bu yaklaşımda dikkat edilmesi gereken bazı hususlar vardır. Özellikle metinlerin konusu iyi seçilmelidir. Çünkü kültürlerarası farklllıklar öğrenenlerde kültür şoku etkisi yaratabilir. Örneğin seks, alkol, din gibi bazı konuları bazı ülkelerde tabu olarak kabul edilebilir. Her iki ders kitabında bu tür konulara yer verilmemiştir. Konular daha çok insanları ilgilendiren ortak temel yaşam deneyimlerine dayanan konulardan seçilmiştir. Örneğin, yeme, içme, seyahat, sanat, edebiyat, çevre, finans, dostluk, ulaşım, sağlık, gelenek-görenek, iletişim vb.

Günümüzde farklı kültürleri tanımak için sadece ders kitapları yeterli değildir. Artık internet üzerinden web tabanlı öğrenme ile yeni iletişim türleri ortaya çıkmıştır: e-posta, tartışma grupları, haber grupları, sohbet grupları, tandem öğrenme - doğrudan otantik (gerçek) iletişim olanakları gelişmiştir. Richter' e göre: "İnternette doğrudan daha gerçekçi üç boyutlu öğrenme imkânı vardır. Ancak bunları anlamak için elbette dil bilmek gerekiyor. Bu kaynakları öğretmen derste kullanırsa daha faydalı olacaktır. Çünkü kültürel unsurlar dille beraber verilmelidir" (Richter, 1998: 14). Dolayısıyla bu yaklaşımın günümüz teknoloji imkânları ile desteklenmesi başarıyı arttıracaktır. Çünkü "Bu kaynaklar kültürel teması sağlar, ancak bu otomatik olarak kültürü anlamak anlamına gelmez. Kültürlerarası diyalogun başarısı her şeyden önce karşılıklı ilişki içinde olmaya ve kendini yansıtmaya hazır olmayı gerektirir” (Richter 1998, 15).

Özetle bu çalışmada yabancı dil olarak Türkçenin ve Almancanın öğretimi için hazırlanmış iki C1 seviyesindeki ders kitabı incelenmiş ve hangi kitapta kültürel unsurlara daha çok yer verildiği kültürlerarası yaklaşım açısından karşılaştırılmıştır. Buna göre Türkçeyi yabancı dil olarak öğrenmek isteyenlerin IYYiT Ders Kitabıyla Türkçeyi ve Türk kültürünü kolayca öğrenebileceği düşünülmektedir. Bu kitabın kültürlerarası yaklaşıma uygun olarak hazırlanmış olması, öğrencilerin hem Türk kültürü hem de bazı yabancı kültürler hakkında bilgi sahibi olmasına ve oradaki benzerlikler ve farklılıkları fark edebilmesine olanak sağlamaktadır. Kültürel alt yapısını görsellerle de zenginleştiren IYYITT Ders Kitabı bu açıdan da em neu Ders Kitabına göre daha geniş bir yelpaze sunmaktadır. Ayrıca IYYiT Türk el sanatları, yazlık sinemalar gibi sadece Türk kültürüne özgü olan kültürel ögelere yer vererek, yabancı öğrencilerin Türk kültürüne ilişkin detaylı bir analiz yapmasına olanak sağlamaktadır.

Yabancı dil öğretimi için hazırlanan kitaplarda kültürel ögelere ne kadar çok yer verilirse dil öğrenmeye olan ilgi ve merak da o kadar fazla olacaktır. Çünkü hedef dilin kültürü ana dile ne kadar uzaksa dil öğrenen kişi yabancı kültürü kendi kültürüyle karşılaştıracak ve tanımaya çalışacaktır. Dolayısıyla yabancı dil öğretimi kitaplarında her seviyeden (A1, A2, B1, B2, C1, C2) deyim, atasözü, coğrafi bilgi, yemek, adet, gelenek vb. kültürel ögelere yer verilmesi dil öğrenimini olumlu yönde etkileyecek ve öğrencilere farklı bakış açıları sunacaktır. Dil öğrenen hedef dilin konuşulduğu ülkeye gittiğinde ister istemez bu tür söz yapılarıyla karşılaşacaktır. Hedef dilin kültürünü ne kadar iyi tanırsa iletişim de o kadar sağlıklı gerçekleşir ve yanlış anlamalar ile önyargılar azalacaktır. Böylece dilin nihai amacı olan iletişim gerçekleşmiş olacaktır.

Sonuç olarak IYİT Ders Kitabıyla Türkçe öğrenen biri Almanca em neu Ders Kitabıyla Almanca öğrenen birisine göre daha fazla kültürel unsurları tanıma fırsatı bulacaktır. Dil öğrenmek demek sadece o dilin yapısını veya kelimelerini öğrenmek değildir. Dilin en önemli unsuru olan kültürünü de öğrenmek gerekir. Bu yüzden IYİT Ders Kitabı hem Avrupa diller öğretimi çerçeve programına göre hem de kültürlerarası yaklaşıma göre daha iyi hazırlanmış bir ders kitabı niteliğindedir. 


\section{Kaynakça}

Aksoy, Ö.A. (1988). Atasözleri ve Deyimler Sözlügü 2, İstanbul: İnkılâp.

Alptekin, C. (1993). Target-Language Culture in EFL Materials, ELT Journal Volume 47

Arıkan, A. (2008). Topics of Reading Passages in ELT coursebooks: What Do Our Students Really Need? The Reading Matrix. V.8. I. 2

Balme- M. P., Schwalb, S. ve Weers, D. (2007). Em neu Abschlusskurs Deutsch als Fremdsprache C1, Ismaning: Hueber Verlag.

Bölükbaş, F., Gedik, E., Göçen, G. vd. (2015). İstanbul Yabancılar İçin Türkçe Ders Kitabı C1, İstanbul: Kültür Sanat.

Bölükbaş, F.,Keskin, F. (2010). Yabancı Dil Olarak Türkçe Öğretiminde Metinlerin Kültür Aktarımındaki İşlevi, TurkishStudies. Volume 5. Issue 4

Bulut, M. (2013). Türkçe Eğitimi ve Öğretiminde Dil ve Kültür Aktarımı Aracı Olarak Atasözleri ve Deyimlerin Önemi, TurkishStudies. V.8. I. 13

Dang. T. C. T. \& Seals, C. (2016) An Evaluation Of Primary English Textbooks in Vietnam: A Sociolinguistic Perspektive, TESOL Journal V.9 I.1

Demir, A. \& Açık, F. (2011). Türkçenin Yabancı Dil Olarak Öğretiminde Kültürlerarası Yaklaşım ve Seçilmesi Gereken Metinlerde Bulunması Gereken Özellikler. Çukurova Üniversitesi Türkoloji Araştırmaları Merkezi, TÜBAR- XXX.

Erdem, M.D.\& Gün, M.\& Karateke, B. İleri Seviye İçin Hazırlanan İstanbul Yabancllara Türkçe Öğretim Setinin Kültür Aktarımı Açısından İncelenmesi, International Journal of Language Academy. V.3. I.1

Hahn, R. (2007). Fremdsprachenlehrmethoden, Norderstedt: Grin Verlag.

Litz, R. A.D. (2002). Textbook Evaluation and ELT Management: A South Korean Case Study, Asian EFL Journal.

Memiş, M. R. (2016). Yabancı Dil Öğretiminde Eğitim Ortamı ve Kültür Aktarımı, Turkish Studies. V.11. I.9

Müller-Jacquier, B. (1994). Thesen zum Interkulturellen Lernen im Fremdsprachenunterricht.

Diskussionsvorlage zur 14. Frühjahrskonferenz zur Erforschung des Fremdsprachenunterrichts, Jena: Uni. Jena.

Neuner, G ve Hunfeld, H. (1993). Methoden des fremdspraclichen Deutschunterrichts, München: Langenscheidt Verlag.

Prodromou, L. (1988). English as Cultural Action. ELT Journal. V. 42. I. 2

Richter, R. (1998). Interkulturelles Lernen via Internet? Zeitschrift für interkulturellen Fremdsprachenunterricht, 3(2). (http://www.spz.tudarmstadt.de/projekt_ejournal/jg_03_2/beitrag/richter1.htm. (Erişim tarihi:29.07.2021).

Rösler, D. (2012). Deutsch als Fremdsprache, Stuttgart : J. B. Metzlar Verlag.

Türkçe Sözlük. (2011). Ankara: TDK Yayınları.

Ünalan Ş. (2014). Dil ve Kültür, Ankara: Nobel.

Yıldırım, A. \& Şimşek, H. (2008). Sosyal Bilimlerde Nitel Araştırma Yöntemleri. Ankara: Seçkin.

Yousefi H.R. (2013). Interkulturelle Kommunikation, Darmstadt: WBG Verlag.

\section{Internet kaynakları}

blablacar.com.tr (erişim tarihi: 29.07.2021).

hurriyet.com.tr (erişim tarihi:29.07.2021). 
kulturportali.gov.tr (erişim tarihi: 29.07.2021).

wikipedia.org.tr (erişim tarihi: 29.07.2021). 